\title{
ON THE MEASUREMENT OF MARKET-ORIENTED REFORMS
}

\author{
Norman V. Loayza \\ World Bank
}

\author{
Raimundo Soto \\ Catholic University of Chile
}

December 2003

\begin{abstract}
This paper presents policy- and outcome-based ways of measuring the progress of market-oriented reforms in both traditional areas of first-generation reform and the areas of institutional reform that have been emphasized lately. These policy areas are the domestic financial system; international financial markets; international trade; the labor market; the tax system; public infrastructure and public firms; the legal and regulatory framework; and governance. For each of them, first, we discuss the general principles underlying market-oriented reform; second, we present various indicators of the policy stance in the area in question; and third, we present various outcome indicators of the policy stance.
\end{abstract}

\footnotetext{
* Patricia Macchi provided excellent research assistance. We are grateful to José Fanelli, Gary McMahon, and Klaus Schmidt-Hebbel for valuable comments and suggestions. The usual disclaimer applies.
} 


\section{ON THE MEASUREMENT OF MARKET-ORIENTED REFORMS}

\section{INTRODUCTION}

\section{Basic Concepts}

A market-oriented reform is a policy measure that allows and induces the competitive participation of private agents in a sector, activity, or market. ${ }^{1}$ Thus, the key concepts underlying market-oriented reforms are private participation and competition among private agents. In most cases, a market-oriented reform implies the reduction in depth and scope of government participation and interference in an economic activity. This is the case of, for example, international trade opening, where the reduction of tariff rates and elimination of quotas are indications of market-oriented reform. In other cases, however, government intervention is necessary precisely to encourage competition. This usually occurs when the "industrial organization" of the activity or sector in question is such that it lends itself to asymmetries of information, moral hazard, and natural monopolies. An example of market-oriented government participation is financial regulation, specifically when it is designed to protect creditor rights and make banking operations transparent.

A pedagogical, though rather simplistic, characterization of market-oriented reform can be made through a "Laffer-curve" approach. ${ }^{2}$ For any economic activity, two extreme government positions can be identified: Full government involvement and total laissez-faire. In between, there is a large variety of levels and types of state intervention. One of them is a market-oriented optimum of government participation. Below such level, there is excessive laissez-faire and the economy would benefit from additional state involvement. Conversely, above the optimum level, there is too much government interference and its involvement should be reduced. Given the historical policy trends

\footnotetext{
${ }^{1}$ The definition of market-oriented reforms we adopt in this paper is rather narrow. It focuses on the issue of economic efficiency and deals with policies and institutions from that perspective. Our definition abstracts from other political or institutional changes needed to initiate reforms or ensure their sustainability. The literature on market-oriented reforms is rich and complex. For essays on basic concepts and meaning of reform, see Williamson (1994, 2000), Sachs (1995), Rodrik (1996), and Kornai (1999, 2000).

2 For an application of the "Laffer-curve" approach to optimal taxation in endogenous growth models, see Barro and Sala-i-Martin (1992).
} 
that favored state intervention, in most cases government involvement is excessive; therefore market-oriented reform implies streamlining it.

In the preceding paragraph, we introduced the notion of optimality without defining it properly. Establishing the link between market-oriented reforms and optimality is complex and here we limit ourselves to a few basic ideas. In this paper, the criterion to define optimality is given by the most efficient allocation and use of scarce resources. For simplicity, we will call it "economic optimality." Our first working assumption is that the participation of private agents in a competitive environment (which is the immediate goal of market-oriented reform) leads to economic optimality. ${ }^{3}$

An important caveat is that a social or political best situation may not coincide with an economic optimum. This would imply that a market-oriented reform that leads to an economic optimum might not necessarily produce a socially desirable outcome, such as the reduction of wealth inequality. However, there is a substantial body of evidence that links economic efficiency with social welfare. ${ }^{4}$ Our second working assumption (or hope) is that economic optimality will result in desirable social outcomes by most criteria and standards. At any rate, assessing the social impact of market-oriented reforms is beyond the scope of this paper.

A second caveat to our analysis regards the political forces that underlie the process of market-oriented reforms. In this paper we enunciate the meaning and measurement of reforms but do not examine the political context that makes them possible and guarantees their continuity. This would require a political economy analysis that weighs the importance of vested interest groups, identifies the "winners" and "losers" of reform, and examines the political process for structural change (including the compensation mechanisms to reduce reform opposition). Our reading of the evidence is that there is no single, well-defined political and institutional framework for carrying out market-oriented reforms. They are possible under dictatorships (e.g., Chile in the 1970s and China currently) or democracies (e.g., India and Ireland in the 1990s). Reforms

\footnotetext{
${ }^{3}$ An excellent collection of articles on the theory behind the link between private competition and economic optimality can be found in Arrow and Debreu (2001).

${ }^{4}$ Some examples of a positive link between economic efficiency (and particularly economic growth) and social welfare are Inter-American Development Bank (1996); Easterly (1999); Barro (2002); Dollar and Kraay (2002); and Demery, Christiaensen, and Paternostro (2002). However, not all agree, as for example Stiglitz (2002); and Stallings and Peres (2000).
} 
occur and are sustained whether their "losers" are compensated (e.g., Mexico's trade reforms) or just silenced (e.g., Peru's labor market reforms). Finally, reforms are adopted gradually and by broad consensus (e.g., Costa Rica) or drastically and by hierarchical imposition even in democratically elected regimes (e.g., Argentina and Peru in the 1990s). Given this ambiguity, it is quite difficult to rate or measure the political context as an element of market-oriented reforms, and we abstain from doing so in this paper.

The final caveat relates to the interconnection between various areas of marketoriented reform. There are synergies between them that must be recognized and exploited, and there are optimal sequences in their implementation that must be respected. This aspect of market-oriented reforms, however, falls beyond the scope of the paper; thus, we treat each area of reform separately. We come back to this important limitation of the paper in the concluding remarks.

\section{Objective and Plan of the Paper}

The objective of this paper is to present ways of measuring the progress of market-oriented reforms in various policy areas. ${ }^{5}$ These are the domestic financial system; international financial markets; international trade; the labor market; the tax system; public infrastructure and public firms; the legal and regulatory framework; and governance. Thus, we cover both the traditional areas of first-generation reform (e.g., international trade) and the areas of institutional reform that have been emphasized lately (e.g., governance).

For each of these policy areas, first, we discuss the general principles underlying market-oriented reform; second, we present various indicators of the policy stance in the area in question; and third, we present various outcome indicators of the policy stance. Policy indicators focus on the regulatory and legal actions taken by government, and outcome indicators consider the immediate impact of those actions in the economy. For example, in the area of international trade, a policy indicator is the level and dispersion of tariff rates, and an outcome indicator is the volume of exports plus imports. It is important to consider both types of indicators: a policy indicator reflects directly government's purported intentions and actions but does not convey whether they have

\footnotetext{
5 Actual attempts to measure the progress of market-oriented reforms are Lora (1997) and Loayza and Palacios (1997). Both deal with Latin America's reform experience of the 1990s.
} 
any practical effect. Conversely, an outcome indicator provides information on practical effects but has the disadvantage of signaling not only policy changes but also a variety of other causes. The two types of indicators complement each other and jointly offer a comprehensive way of assessing the progress of market-oriented reforms.

The plan of the paper is the following. In section II we deal with each of the 8 policy areas in turn. It is the longest and most substantial section of the paper. Section III offers some concluding remarks. Finally, the appendix contains a comprehensive list and brief description of data sources on reform indicators for each area outlined in the text.

\section{MEASURING MARKET-ORIENTED REFORMS}

\section{A. Domestic Financial System}

1. General Principles. Market-oriented reforms in the domestic financial system consist of the liberalization of credit allocation accompanied by prudential norms and monetary stability. This can lead to the development of sound financial institutions. Well-functioning financial systems act positively on economic efficiency through different channels. First, they facilitate the exchange of goods and services, acting as intermediaries between buyers and sellers. Second, they facilitate the trading, hedging, and pooling of risk. Third, they mobilize savings, and thus, allocate resources for investment. Finally, financial systems monitor managers and exert corporate control by allowing the market to price companies according to their expected performance (see Levine 1997).

The most common pattern of financial reform in developing countries has been, first, radical liberalization, and second, implementation of prudential norms that moderated the initial liberalization. In many countries around the world, financial repression was the norm in the 1960s, 70s, and 80s. There was the belief that economic development could not proceed without financial resources being directed to key segments of the economy and that there was no guarantee that the private sector on its own would provide those resources. According to this logic, governments had to intervene to direct financial resources to the areas most conducive to economic development. This was done through a variety of instruments, some of them direct --such as the creation of development banks for agriculture, fishing, and construction-- and 
others indirect --such as credit quotas and subsidized rates imposed on private banks. Unfortunately, government officials proved to be lousy bankers and credit was grossly misallocated.

The first reforms against financial repression consisted of radical liberalization. That also proved to be a mistake that led to many a financial crisis. Market failures brought about by moral hazard and adverse selection are endemic to financial systems. The implementation of prudential regulations is necessary to control market failures such as excessive risk taking and monopolistic credit allocation (e.g., "related" lending). In this way, these regulations defend creditor rights, promote competition, and prevent crises. It is not easy to determine when a regulation ceases to be prudential and becomes excessive, but at least in principle financial regulations have the potential of moderating extreme liberalizations to produce a competitive and efficient financial system.

Financial liberalization and prudential regulation can only be successful in the context of monetary stability. Even the most efficient and well-regulated financial system cannot withstand the negative consequences of macroeconomic imbalances. An essential ingredient to ensure macroeconomic stability is a well focused and properly working central bank. ${ }^{6}$

2. Policy indicators. As noted above, there are three fields of policy in marketoriented reform related to the domestic financial system. They are liberalization, prudential regulation, and monetary stability.

As its name indicates, financial liberalization attempts to remove the constraints imposed on banking and capital markets during the period of financial repression. Generally speaking, this means letting the private sector run credit institutions and allowing the corresponding markets determine the quantity, variety, and prices of financial products. In such an environment, a series of interrelated financial markets and services develop, from traditional banks and insurance companies to stock and bond markets. In practical terms, we can mention the following specific policy indicators of financial liberalization: the removal of interest-rate controls, the reduction of taxes on

\footnotetext{
${ }^{6}$ Naturally, macroeconomic balance cannot be achieved by monetary and exchange-rate policy alone. Fiscal discipline is a crucial ingredient, and we address it in this paper from the complementary perspectives of various market-oriented reforms. Fiscal balance is induced by an independent central bank,
} 
financial transactions, the elimination of mandated credit to "priority" sectors, the privatization of state banks, the reduction of reserve requirements held at the Central Bank, and the elimination of prohibitions on private institutions to offer a broad array of financial services (see Bandiera et al. 2000; Roubini and Sala-i-Martin 2001).

The policy indicators on the regulatory framework are subtler and require deeper examination. In broad terms, the objective of prudential regulations is to protect creditor and shareholder rights against excessive risk taking and uncompetitive practices on the part of financial institutions. In most instances the implementation and monitoring of these regulations entails the formation of a supervisory agency. It is debatable whether this agency should be independent of government and/or given broad powers over banks and other financial institutions. However, there is agreement that its main role is to promote the transparency of dealings and accounts on the part of financial institutions and corporations related to them. The transparency and accuracy of financial records should allow private monitoring on banks and other financial institutions. However, it can be argued that transparency is not enough and that it should be complemented with specific rules imposed on financial institutions, such as prohibition of related lending, sufficient capitalization of financial assets, and adequate matching of assets and liabilities in terms of duration and currency denomination. In this regard, a suitable policy indicator can be developed from the portion of regulations that are adopted from wellestablished international criteria, such as the Basle convention and related agreements. Lastly, but not less importantly, prudential regulation should establish a clear and predetermined procedure for the liquidation of assets of failed companies and banks. To accomplish this, a modern and efficient bankruptcy law is essential. For principles and data on financial regulation, see La Porta et al. (1998), and Caprio, Barth, and Levine (2001), World Bank (2003).

Turning to monetary stability, a right mixture of monetary, exchange-rate, and fiscal policies is essential for this purpose. As mentioned above, fiscal policies are addressed indirectly in various areas of reform discussed in the paper. Here, we concentrate on monetary and exchange-rate policies. For them, the most important policy

by an efficient tax system, by eradication of deficit-producing public firms, and by improvements in governance, among other reforms. 
indicator is the existence of an independent central bank with a clear mandate to promote low and stable inflation. More precisely, although coordination between fiscal and monetary authorities can occur at the level of objectives and forecasts, the central bank should retain independence in the management of its policy instrument, whether an interest rate or a monetary aggregate. Moreover, experience indicates that central banks are able to promote monetary stability when their main target is keeping domestic price inflation low, stable, and predictable (see Sterne 2002). When central banks have broad mandates that include from long-run growth to exchange rate stability, they are usually ineffective not only in obtaining these ambitious goals but also the basic one of inflation stability. Thus, promoting monetary stability entails the use of a clear monetary policy framework and the avoidance of policies that provoke misalignments in the real exchange rate and other key relative prices. One monetary policy framework that has proven quite successful in this regard is inflation targeting (see Loayza and Soto, 2002); it is not the only one, however, and the appropriate monetary regime for each country remains an empirical issue.

3. Outcome indicators. Market-oriented reforms in the domestic financial system should, in principle, lead to greater depth and activity of financial markets, more private sector participation and competition in those markets, lower incidence of financial crises, and stronger monetary stability. The outcome indicators we propose below correspond to these broad categories.

For analytical and completeness purposes it might be useful to distinguish between various financial markets, such as bank, stock, bond, and insurance markets. However, it is difficult to generalize across countries as to the expected performance of various financial markets after liberalization. Indeed, there is no clear common international pattern for their relative development (i.e., with respect to each other), and the literature does not find any solid evidence that one of them performs financial services better than the rest (see Demirguc-Kunt and Levine 2001). There is, nonetheless, some evidence that these markets are complementary. Thus, we take an eclectic perspective and consider jointly the development of banking and stock markets (which can be extended to other financial markets, if necessary). 
On greater depth and activity of financial markets, consider the following outcome indicators. In the case of banking, good measures of depth and activity are given by the ratios of a broad monetary aggregate that includes saving and demand deposits, such as M2 or quasi-liquid liabilities, to the size of the economy, represented possibly by GDP. In the case of stock markets, the ratio of stock-market capitalization to GDP is a good measure of depth, and the ratio of value traded to stock-market capitalization, a good measure of activity.

On larger participation of the private sector and stronger competition, we can consider some variants of the indicators on depth and activity. For instance in the case of banking, a good indicator of financial depth that focuses on the private sector is domestic credit allocated by private commercial banks to the private sector, divided by GDP. In addition, as indicators of stronger private competition, we can consider reductions in concentration ratios within banking and stock markets (for instance the share of the largest 4 banks in total banking assets), in the average spread between deposit and lending rates (controlling, if possible, for financial transaction taxes), and in the average profit margins in banking and stock-market trading. The database developed by Beck, Levine, and Demirguc-Kunt (1999) provides comprehensive, cross-country and timeseries information on depth, competition, and private participation in financial markets.

When considering the measures of depth and activity of financial markets, it is important to focus on their general trend and abstract from temporary movements, such as those produced by short-lived credit expansions. Indeed, it would be informative to consider as a sign of improvement not only an increase in the trend but also a reduction of the volatility around it. ${ }^{7}$

Although it should be expected that a certain fraction of financial institutions fail from time to time (as in any other line of business), systemic financial crises are an indication that either the regulatory framework is not appropriate or monetary policy is inadequate. Systemic financial crises can be detected in a number of different ways, such as large fluctuations in domestic credit, bank runs in otherwise healthy institutions, and massive accumulation of poor-performing loans. There is a large literature on systemic

\footnotetext{
${ }^{7}$ The long-run trend and cyclical volatility of a given series can be obtained by applying filters such as the Hodrick-Prescott, Baxter-King, and other procedures that separate permanent from transitory changes.
} 
financial crises, and some of that includes precise measures of the occurrence and magnitude of the crises; in particular, see Caprio and Kinglebiel, 2001. There is also an important literature on "early warning" indicators, which focuses on identifying macroeconomic and financial variables whose changes precede debt crises, including those related to balance of payments, banking, and public debt. Leading examples of this line of research are Kaminsky, Lizondo, and Reinhart (1998); and Goldstein, Kaminsky, and Reinhart (2000).

Finally, on stronger monetary stability, the most obvious indicator consists of low and stable domestic price inflation. Nonetheless, a more complete analysis requires considering foreign exchange rate and interest rate movements. Fluctuations in exchange and interest rates are to be expected in dynamic and flexible capital markets; therefore, by themselves, these fluctuations do not indicate lack of monetary stability. In order to detect monetary instability even before it manifests itself in inflation shocks, it is necessary to analyze the degree of misalignment in real exchange and interest rates with respect to their equilibrium values. As the recent Argentinean crisis painfully illustrated, low inflation and motionless exchange rate do not mean monetary stability but, far from it, may hide large misalignments. Some seminal work on equilibrium and exchange rates are Edwards (1988), Williamson (1993), Elbadawi and Soto (1997), and Hinkle and Montiel (1999).

\section{B. INTERNATIONAL FINANCIAL MARKETS}

1. General Principles. Market-oriented reforms in international financial markets basically consist of removing restrictions on cross-border flows of debt, equity, and financial services. As in the case of domestic financial markets, market-oriented reforms dictate that financial liberalization is accompanied by prudential regulations directed at minimizing market failures.

The globalization of financial markets is possibly the area of reform whose benefits and costs are most hotly debated (see World Bank, 2001). Weary of its potential dangers, Keynes advised, "above all, let your finance be national." It is argued that the main disadvantage of financial globalization for developing countries is that they may become vulnerable to external shocks that are difficult to manage and control. The contagion of capital market volatility and crises is a major concern not only for its effects 
on financial asset prices and flows but also for its negative consequences on real activity and employment. Such is the case, for instance, when the flows of foreign investment suddenly stop whenever international markets become disturbed.

There are, nonetheless, important advantages associated to financial globalization. They can be summarized as the positive effects of a substantial increase in the supply and quality of financial products. These developments are brought about by both the direct participation of foreign financial institutions and the upgrading of domestic institutions due to stronger competition. For firms and individuals in need of financial resources, financial globalization carries a decrease in their cost of capital, an improvement in financial institutions' capacity to assess and monitor the profitability of their investment, and a reduction of their perceived risk (given that portfolio expansion allows the diversification of local risk). For institutions and individuals seeking to allocate their savings, financial internationalization opens up the array of available investment opportunities, allowing them to minimize their portfolio risk and giving them the best possible return. ${ }^{8}$

Even if the arguments in favor of globalization remain unconvincing to some people, the globalization of financial markets is a characteristic no modern society can escape. The radical and continuous improvements in the technology of communications and financial transactions are making capital-account restrictions increasingly futile. Market-oriented reforms should be directed at accepting this reality and defining the role of government regarding prudential regulation.

Finally, the relationship between market-oriented reforms in the domestic financial system, in international financial markets, and in macroeconomic policy is an interesting and complex one. On the one hand, it is often argued that a precondition for financial integration is the development of domestic financial markets. However, domestic financial liberalization and prudential regulation rarely occur without the incentives created by the integration with world financial markets. Therefore, a sensible

\footnotetext{
${ }^{8}$ Naturally, there are limits to the beneficial impact of financial globalization. To a large extent, however, these limits are not due to excessive market participation but, rather, to incomplete markets that impede full risk diversification. A case can be made that in some instances government participation is necessary to induce markets to provide key diversification instruments. For example in order to deal with terms-of-trade (TOT) risk, Caballero (2002) argues that governments of small economies should issue TOT contingent
} 
recommendation seems to be to advance in both fronts -domestic and international-- in a balanced manner. Macroeconomic stability does appear to be a necessary pre-condition for both domestic and international financial reform. Financial deregulation unleashes market forces that take advantage of the arbitrage opportunities created by macroeconomic disequilibrium (for example, speculative attacks in the face of overvalued exchange rates). In principle, this can act as a disciplining device on macroeconomic policy; however, often times, the correction does not occur orderly and can lead to serious crises --such as those in East Asia in 1997 and Argentina in 2002.

2. Policy Indicators. Market-oriented reform in international financial markets generates two types of policy indicators. The first consists of measures of liberalization in cross-border financial services, equity flows, and debt transactions. The second consists of measures of prudential regulation and control.

International financial liberalization rarely occurs in one step. Rather, it is a process whereby the constraints on various services and transactions are removed gradually. However, for simplicity, we here present the indicators in the form of yes/no questions. A crucial policy indicator that spans financial services, equity flows, and debt transactions is whether domestic and foreign residents have free access to foreign exchange at all times. For financial services, specifically, the key indicators are whether foreign banks and other financial institutions can own financial assets in the country; whether they can operate freely; and whether domestic firms, individuals, and institutions (such as pension funds) can use foreign financial institutions wherever they may be based.

For equity flows, the main indicators consist of whether foreign residents can own shares in listed or unlisted domestic companies (i.e., foreign portfolio and foreign direct investment); whether domestic residents can open and maintain equity positions in foreign firms; and whether both foreign and domestic residents have the ability to repatriate their earnings and liquidate their equity investments. Regarding debt transactions, they have been traditionally available to governments only; market-oriented reform dictates that private agents be able to tap debt markets as well. Policy indicators

bonds, which private financial companies could then use as benchmark for a fuller array of financial instruments. 
of reform in this area consist of the removal of restrictions to obtain commercial credits and consumer loans, to issue corporate bonds, and to provide and receive credit guarantees in domestic and international markets, regardless of the country of residence. The most comprehensive and authoritative cross-country database on policy indicators of international financial reform is the Annual Report on Exchange Arrangements and Exchange Restrictions, prepared and published by the International Monetary Fund. Its main drawback is that, in most instances, the indicators are binary (i.e., yes/no type) and, thus, do not represent accurately the actual extent of liberalization.

The measures of prudential control and regulation are more difficult to assess. A general indicator is whether the country has adopted international standards for banking and capital-market disclosure of information, asset capitalization, and reserve requirements. Beyond that, it is unclear whether additional regulations actually correct market failures (as reflected in "herd" behavior, program trading, and purely speculative attacks) or, rather, create unnecessary obstacles to financial integration. An argument could be made in favor of capital controls that discourage destabilizing short-term flows, such as those implemented in Chile for most of the 1990s (see Gallego, Hernández, and Schmidt-Hebbel 2002 for an authoritative evaluation of capital controls in Chile). However, it seems that in order to reduce the potential negative effects of external financial integration, it is more important to eliminate potential arbitrage opportunities derived from macroeconomic disequilibria (particular, real exchange rate misalignment), and eradicate implicit insurance and subsidies that induce speculative behavior (such as unsustainably low domestic interest rates). Creative indicators could be derived from policy changes in this regard.

3. Outcome indicators. The main outcome indicators of reform in international financial markets can be grouped in the following categories. The first one corresponds to the effect on the domestic financial system. The second considers the quantities and prices of cross-border services and flows. The third category comprises indicators of external vulnerability.

Market-oriented reform in international financial markets should have effects on the domestic financial system that are akin to those of domestic financial reform. That is, there should be an increase in the volume of private financial assets and a decrease in the 
cost of capital (including the reduction of profit margins and interest-rate spreads) in the domestic financial system. These indicators are discussed in the section above.

The second group of outcome indicators refers directly to international financial integration. Some of the most important indicators are, first, an increase in the participation of foreign banks and other financial institutions in the domestic market, measured for instance by the ratio of foreign to total number of banks or the market share of foreign-owned banks. Bankscope is the premier data source about banks around the world. The second indicator is an expansion in the stock of domestic assets held by foreigners, and likewise, an increase in foreign asset holding by domestic residents, with the resulting rise of gross capital flows in the balance of payments. It is not clear, however, what type of asset should increase the most as result of financial globalization, whether gross foreign direct investment (FDI), portfolio investment, or debt. This should be determined by their relative scarcities in the portfolio of assets. In recent reform experiences, FDI has been the predominant form of foreign assets. The most important source for data on capital flows is Balance of Payments Statistics published annually by the International Monetary Fund. For foreign asset stock data, see Lane and MilesiFerreti (1999) and Kraay et al. (2000).

Finally, measures of external vulnerability can represent outcome indicators of the government's failure to provide for adequate supervision, to ensure macroeconomic equilibrium, or to eliminate implicit insurance or guarantees for speculative flows. Some of them are, high black-market premium on foreign exchange, substantial real exchange rate misalignment (which, particularly in the case of overvaluation, might indicate the need for a drastic adjustment), large domestic-foreign interest rate spreads (which, after accounting for risk premia, may indicate the presence of controls), and the classic indicators of high levels of external debt (particularly of short duration) relative to GDP, exports, or foreign reserves. For a discussion of leading indicators on external vulnerability, see Goldstein, Kaminsky, and Reinhart (2000), and IMF (2000).

\section{INTERNATIONAL TRADE}

1. General Principles. There is a large empirical literature suggesting that economies that are more open to international trade have higher rates of growth, as a result of higher investment and sustained gains in factor productivity (Frenkel and 
Romer, 1999). Along with faster growth rates, trade openness brings about industrial transformation, changes in the structure of employment, and a decline in poverty (Dollar and Kraay, 2001).

The literature points out five channels through which trade affects economic growth. First, trade leads to higher specialization and, thus, gains in total factor productivity (TFP) by allowing countries to exploit their areas of comparative advantage. Second, it expands potential markets, which permits domestic firms to take advantage of economies of scale. Third, trade diffuses both technological innovations and improved managerial practices through stronger interaction with foreign firms and markets. Fourth, freer trade lessens anti-competitive practices and rent-seeking activities by domestic firms that are mostly unproductive. Finally, trade liberalization reduces the scope for corrupt practices by government officers.

The empirical evidence indicates that the relationship between economic growth and openness is indeed positive and significant, working through both raising domestic investment and enhancing efficiency gains (Dollar and Kraay, 2001b). This is the case even after controlling for other determinants of growth, determinants that in turn may be positively affected by trade openness. The relationship between productivity growth and trade-liberalization reforms, on the other hand, is complex and dynamic. Some countries benefit more than others from trade liberalization. In some countries the response to liberalization comes quickly after the reforms, while in others adjustment is a slow process and TFP gains takes time to materialize. This suggests, again, that trade reforms must be evaluated in conjunction with other structural reforms.

Trade reform aims, first, at introducing greater external competition into the previously protected domestic markets and increasing economic efficiency at the level of individual firms by using scale economies and comparative advantages. In this regard, it is crucial to eliminate preferential treatment for specific sectors. A secondary goal of trade reform is to expand the variety and quality of goods and services available to consumers. These objectives are usually accomplished by lowering tariffs and effective protection, eliminating non-tariff barriers, reducing administrative requirements for imports and exports, and eliminating distortions in exchange rates and the financial sector. 
This is certainly one of the areas in which reforms are likely to encounter significant opposition from vested interests and pressure groups, as well as from producers facing adjustment costs arising from the often-substantial changes in relative prices. To be effective, trade liberalization should induce significant changes in relative prices, which would signal producers to relocate resources towards more productive ends. It would also bring about the end of state protection and privileges to sectors or individuals. The experience of some developing economies suggests that a preannounced liberalization schedule and an unrelenting commitment towards liberalization tend to ameliorate lobbying pressures and provide producers the confidence to undertake the necessary relocation of resources.

2. Policy indicators. Measuring how reforms affect trade openness is challenging mostly because there is a wide array of policy instruments available to affect external trade beyond tariffs. Consequently, trade reforms entail eliminating non-tariff barriers (such as quotas, exemptions, special permits, and discriminatory practices), reducing the dispersion of tariff rates, and reducing the average level of tariffs.

The simplest case of reform occurs when protection is based only on taxes (or subsidies) levied on imports and exports with no other restrictions. In such case, average tariffs weighted by their respective shares in world imports or in production can be directly used as a measurement of the change in openness. The higher the average level and dispersion of tariffs and para-tariffs (for example, duties and customs fees), the more distorted the trade outcome. Reform indicators would then be (1) the change in the tariff level, and (2) the change in the dispersion in tariff rates. The interpretation of these indicators should be cautious because some countries rely on non-uniform tariffs. In such case, even with the same average tariff rate, the effect of protection on trade will differ, depending on which goods are taxed at high rates and which at low 9 .

Measuring trade reform is more complex when countries use additional non-tariff barriers. These include foreign exchange rationing, import licensing requirements,

\footnotetext{
${ }^{9}$ An alternative indicator is the average collection rate, calculated as the ratio of import duties collected to value of imports. The collection rate seems more appealing at first blush, since legal rates do not mean much when there are widespread exemptions or smuggling, as noted by Nash and Andriamananjara (1997). But collection rates may also be misleading when exemptions are concentrated in goods that do not compete with domestic production, as is common in developing countries, or in imported inputs. In such
} 
reference prices, domestic content requirements, and export licensing requirements. In such case, tariffs may become redundant, providing little additional protection to domestic producers. A measure used to evaluate the level of non-tariff restrictions is the weighted share of tariff-code lines covered by non-tariff barriers (licenses, quotas, prohibitions) as a percentage of all tariff code lines, using as weights the respective shares in world trade, imports or domestic production. This index is probably the most useful as an indicator of how much the NTBs protect domestic industry. But even this is not very reliable, since the actual effect of the NTBs varies a lot across products and across countries, and this kind of index cannot show which are binding (and how much these raise domestic prices) and which are not.

A complimentary measure of trade limitations is the existence of multiple exchange rates and administrative limitations such as mandatory surrender of exports proceeds at the central bank, export and import licenses, etc.

3. Outcome indicators. Trade policy reform is effective to the extent that it encourages undistorted and larger volumes of trade. The first two outcome indicators presented below are related to, respectively, changes and levels of trade intensity. Their usefulness as indicators of reform is based on the proposition that trade liberalization leads to larger flows of imports and exports, relative to GDP.

Using the percentage change in the ratio of real imports plus real exports to real GDP as an outcome indicator of trade reform rests on the assumption that average changes in this ratio that occur in the medium-term are mostly caused by policy changes. Under such assumption, this indicator can be used to compare improvements in trade openness over time. A variation of this measure is the ratio of imports to aggregate consumption. The latter is probably a more reliable indicator of restrictive trade policy than the former since in most developing countries it is imports of consumption goods that are the most stringently restricted. However, using total imports to calculate this ratio implicitly assumes at a minimum that the proportion of consumer imports in total imports is the same in time.

cases, high rates on competing imports and low rates on inputs can produce a low collection rate but high effective protection. Consequently, we suggest using the level and dispersion of tariff rates. 
The structure-adjusted trade intensity (SATI) consists of the ratio of real imports plus real exports to real GDP, corrected for certain structural characteristics that determine a country's trade, such as its size (both area and population) and transport costs. This indicator proxies for the level of trade explained by trade policy, and therefore allows for comparisons across countries with different structural characteristics. Frenkel and Rose (1999) extend this simple statistic to derive a SATI from a gravity model, in which trade measures can be systematically weighted against structural factors. One obvious problem with this approach is that the results are only reliable to the extent that the model used to form the counterfactual incorporates all the relevant determinants of trade.

A third generic variety of indicators consists of those calculated from a comparison of domestic and border prices of similar products. Where these can be calculated, they have the advantage of capturing the effects of non-tariff barriers, as well as tariffs. They also are easier to interpret economically than some other quantity-based measures. The major disadvantage of these measures is that they require data that may not be readily available in developing countries. Domestic prices of individual goods must be compared to the border prices of those same goods, adjusted for transport costs, distribution markups, and (unless the goods are exactly the same) quality differences. This kind of exercise is difficult and time-consuming, and has been carried out for few developing countries on a regular basis. As a second-best indicator, it is advisable to use the changes in both domestic and border prices, which represents a milder version of the arbitrage of price differentials.

A fourth indicator usually utilized is the black market premium on foreign exchange, which is a proxy for the excess demand for foreign exchange. However, demand for imports outside of official channels is only one source of excess demand for foreign exchange. The other major source is the capital account (in particular, capital flight), which can create a high premium when the capital account is not open, even in an economy with a relatively open current account with few barriers.

To the extent that trade policy changes incentives in an economy, the composition of trade flows in terms of goods and trade partners should also change after reforms. More open and less regulated economies should tend to diversify better their export and 
import portfolios than heavily regulated, closed economies. This may come as the natural result of risk hedging by private sectors exporters and importers operating without government restrictions on international trade. Indicators of diversification are the change in the share of the largest three (or five) trade partners in total exports or in total imports, as well as the change in the participation of the three (or five) main exports or imports in total trade.

Finally, in several economies trade liberalization has been accompanied by trade agreements. In some occasions, these agreements are the result of the genuine desire to create additional trade opportunities and engage in more active competition. As such, they can have a positive impact on the economy. Moreover, for economies with relatively weak institutional conditions, a free trade agreement can help deter reform reversal. However, in most cases trade agreements tend only to divert trade from the international community towards the partner in the agreement. For this purpose governments increase protection of local firms against third-party producers, thus misallocating resources, reducing overall efficiency, and usually leading to stagnation in productivity and innovation.

\section{The LABOR MARKET}

1. General Principles. Market-oriented reforms in the labor market mainly consist of removing distortions, many of them induced by government regulations that make labor too costly and risky relative to its abundance in the economy. These reforms may also involve government participation to reduce monopolistic power in managerlabor relations, such as those potentially exercised by industry-level worker unions or large owners' associations. Therefore, as in other sectors, market-oriented reforms in the labor market usually entail deregulation but in some instances require specific government intervention.

Ideally, undistorted and competitive labor markets enjoy the flexibility that allows the economy to adjust efficiently to changes in aggregate demand coming from external

and internal sources. In times of negative shocks, a flexible labor market minimizes the rise of unemployment, thus promoting a timely output recovery. In times of booming economic activity, labor market flexibility guarantees that output expansion is accompanied by full employment and rising real wages. 
Undistorted and competitive labor markets are important not only for the shortterm adjustment to shocks, but also to obtain "broad-based" long-run growth, the kind of growth that brings about a rise in income not only to the owners of physical capital, but also to the majority of workers. When firms perceive that labor is too costly or risky, they choose investment strategies that are excessively capital intensive. This produces labor-market segmentation (i.e., formal and informal labor) that is particularly acute in labor abundant countries and that is not conducive to broad-based growth.

To summarize then, the main objectives of market-oriented reform in labor markets are to make labor markets more flexible, more competitive, and less segmented.

2. Policy Indicators. The policy indicators of labor-market reform can be grouped in four broad categories: Constraints on hiring and firing of workers; wages, compensation, and payroll taxes; mechanisms for negotiation and peaceful resolution of labor disputes; and public employment.

Constraints on hiring and firing have several aspects; we now discuss a few indicators on some of the most important of them. The first policy indicator is whether labor legislation considers dismissals caused by economic difficulties of the firm as justified; if not, legislation would be ignoring that in an active economy some firms and sectors shrink and that this process requires the dismissal of some workers. The second indicator is whether at least a portion of severance payments are periodically deposited in accounts in the name of the workers so that these funds and their associated market yields are available to workers when they are fired or resign from the firm. The existence of these funds signals that labor legislation considers severance payments as deferred compensation rather than as penalties designed to prevent firms from shedding labor. The third policy indicator considers directly the portion of monetary compensation for dismissal that represents an actual cost to the firm; this compensation is usually mandated as a multiple of the last monthly wage and varies with the level of workers' seniority. High compensation for dismissal is especially distortionary for the labor market and costly to the firm if economic difficulties are treated as unjustified causes for dismissal. In this case, firms find themselves trapped in a situation where downsizing is the only way for them to manage their economic difficulties but is too expensive to undertake. The fourth policy indicator is whether legislation imposes restrictions on temporary 
contracts; this type of contract is needed to fulfill particular needs of the firm and when, as result of an active economy, new and rather uncertain ventures frequently appear. In economies in which rigid constraints on the hiring and firing of permanent workers exist, temporary contracts may provide a way, albeit imperfect, to make labor markets more flexible. However, to avoid market segmentation within the firm, it is important that when temporary contracts become less restricted, permanent contracts be also liberalized.

The second category of policy indicators on labor-market reform deals with wages, compensation, and payroll taxes. The general principle of reform in this area is to allow overall compensation to reflect both workers' productivity and their relative scarcity in the economy. Some of the most important policy areas to consider are the following. The first indicator is whether mandated minimum wages are binding in the sense that they are keeping some workers (mainly the less skilled and the young) out from the active labor force. The second indicator is related to social-security contributions and payroll taxes, such as those for disability, death, sickness, maternity, work injury, unemployment, and family allowances. The policy reform in this case consists of, first, strengthening and making explicit the link between social-security contributions and each worker's received benefits and overall compensation; and, second, lowering the contributions so as not to make labor unduly expensive. A rather crude policy indicator in this area is the rate of total social security contributions (usually as a percentage of the wage). A more complete indicator would consider whether social contributions make labor costs excessive (relative to market-clearing levels) and whether contributions and benefits are closely connected at the individual level.

The connection between social security contributions and each worker's received benefits merits further discussion. If the link is strong, then social security contributions are not distortionary but represent a form of remuneration to the worker. As such, they can be taken into account when firms and workers negotiate on the remuneration package. On the other hand, if the link is weak, social security contributions become a tax on both firms and workers without corresponding benefits. A traditional example of a weak relationship between contributions and benefits is the retirement pension system of the pay-as-you-go type; in this case, what is contributed during working years bears little relation with what is received at retirement. 
The third category of policy indicators on labor market reform concerns the mechanisms for negotiation and peaceful resolution of labor disputes. Market-oriented reforms in this area focus on confining government involvement in manager-labor relations to the expeditious resolution of labor disputes, for instance through specialized judicial courts and arbitrators. This implies taking government out of the negotiation process and placing it in the role of contract enforcement. Then, some specific policy indicators in this regard would consider whether legislation allows for decentralized and flexible collective bargaining; whether workers are allowed to choose their own unions (which would generate more efficient worker representation through improved competition and contestability); whether labor legislation does not induce labor stoppage by making one party (usually the firm) bear most of its costs; whether labor legislation allows labor strikes only when they are clearly connected to specific contractual claims between workers and their corresponding firms; and whether there are courts and arbitrators specialized on labor disputes.

The last category of policy indicators on labor reform is related to the prevalence of public employment. In many developing countries, public employment has traditionally been used both as a way to solve unemployment problems during economic downturns and as a political tool to reward allegiance to the governing party. Therefore, the process of hiring public employees has often neglected to adequately match workers to the needs of public administration. This overstaffing and excessively high remuneration in the public administration (relative to productivity) has bid up labor costs in the private sector and created little incentive for training and human capital development in the public sector. A policy indicator of reform in this area is the initiation of a public sector downsizing program, one that provides adequate compensation and training to departing staff and prevents the state from losing its comparatively most productive personnel.

On these policy indicators, the main data source consists of various publications by the International Labor Organization, such as the Labor Statistics Database and the ILO Conventions and Recommendations. The drawback of ILO sources is that the relevant information is dispersed and not always comparable across countries. These problems are remedied to a large extent in the database of labor market indicators 
collected by Rama and Artecona (2000). It includes 44 indicators on policies and outcomes related to labor markets in 121 countries since the 1950s. A more recent attempt of providing cross-country information on labor market policies is given by Djankov et al. (2003). These data set is quite comprehensive in terms of country and thematic coverage; however, it lacks time-series variation as its observations correspond to the early 2000s only.

3. Outcome Indicators. We consider general and specific outcome indicators of labor market reform. General indicators assess outcomes from the perspective of the overall functioning of labor markets, while specific indicators measure closely the immediate impact of particular policy changes.

Among general indicators, we should look for measures of improved adjustment flexibility of labor markets to aggregate and industry-specific shocks and for indications of reduced labor market segmentation. Two broad outcome indicators are the rates of unemployment and underemployment. These data are readily available from national or labor statistics; they are difficult to compare across countries but, with enough care, are useful for overtime comparisons. More precise measures of flexibility, although more difficult to obtain, are given by sectoral-, gender-, and age-specific data on labor force participation, worker turnover rates, average time between jobs, and labor force dropout rates (for an application to several Latin American countries, see Micco and Pagés 2002). Regarding labor market segmentation, a "quantity" approach would measure the share of the labor force in the informal sector, defined as the segment of the economy that does not comply with labor-market regulations (see Loayza 1996). A "price" approach would compare wages and total compensation between similarly qualified workers across different firms (in terms of size and age, for example) in comparable industries and sectors.

Specific indicators measure the immediate outcomes of policy changes. In fact, we can group these outcome indicators using the same taxonomy as the one used for policy indicators. On hiring and firing of workers, the best indicators are turnover rates, unemployment duration, and unemployment rates --cited above as general indicators. Various worker ratios --such as the ratio of temporary to permanent workers and the proportion of workers according to seniority-- are also useful but require an estimation of 
their "equilibrium" values in order to make relevant value judgments. On the connection between social security contributions and individual benefits, the literature has focused on pension reform and used as outcome indicators the extent to which pension regimes are based on individual capitalization systems. The highest score is given to pension regimes that feature a fully funded capitalization system with individual accounts managed by private companies; and the lowest score is given to pension regimes that are mostly based on a pay-as-you-go system (see Samwick 2000 for a cross-country application). Ideally, similar indicators could be constructed for other social security benefits (such as health insurance, family allowances, etc.)

Regarding the mechanisms for negotiation and peaceful resolution of labor disputes, a key outcome indicator is the incidence of worker strikes. This can be measured, for instance, by the number of hours not worked due to strikes, per year and worker in the modern sector. The extent of unionization has also been used as an indicator of the lack of efficiency of manager-worker relations and even the degree of government involvement in the negotiation process (which would be the case if legislation favors the formation and membership of unions). However, without contextspecific analysis, it is difficult to ascertain whether unionization responds to excessive government regulations, ineffective labor-dispute courts, or the most prevalent forms of industrial organization in the country.

Finally, on the pervasiveness of public employment in the economy, common indicators are the ratio of public to total employees in the non-agricultural sector and the share of government expenditures devoted to the public sector payroll, among other measures. The first indicator denotes the labor resources in the economy occupied by the public sector, while the second measures public employment in relation to the size of government (a large share is likely to represent overstaffing in the public sector).

As noted before, the database compiled by Rama and Artecona (2000) contains useful cross-country information on a number of labor outcome indicators, such as unemployment rates, wages, conditions of work, trade unions and collective bargaining, and public employment. 


\section{E. The TAX SySTEM}

1. General Principles. Market-oriented reform in the tax system seeks to minimize the distortionary effect of taxation on private activity while generating sufficient revenue to finance government operations. The tax system is distortionary when it penalizes specific activities or assets without a clear public-externality justification; when it creates uncertainty as to the profitability of various economic activities; when it discourages high levels of effort, work, and investment; and when it creates incentives to undertake wasteful actions devoted to tax evasion and avoidance. By omission, taxation is also distortionary when it does not generate enough public revenues and, thus, leads to a growing public debt that crowds out investment and creates macroeconomic instability.

In most unreformed tax systems, tax laws are onerous and tax-collection agencies weak. The formal sector endures the crippling burden of taxation, the informal sector is limited by its poor access to legal and financial services, and the whole economy suffers from the consequences of insufficient public revenues, that is, public debt, macro instability, and deficient public goods and services (see Loayza 1996). This situation has an effect on the structure of taxation: Given that the state's ability to generate revenues from domestic income and indirect taxes is undermined, the state resorts to obtaining revenues through both inflationary seignorage and import and export taxes (which can be more easily monitored). It should then be clear why tax reform is an important complement to reforms in the areas of international trade (e.g., lower tariff rates) and macroeconomic stabilization (e.g., inflation reduction).

In unreformed systems, taxation is characterized by tax rates that are high in average, heterogeneous across sectors, and unpredictable over time (see Shome 1992). Therefore, to summarize, the objectives of market-oriented reform in the tax system are to reduce and make more stable the tax burden on the formal sector; encourage informal firms to become formal; eliminate unjustified discriminatory treatments; and create the conditions for international trade liberalization and macro stabilization. The goal of market-oriented tax reform is not necessarily increasing public revenues but making taxation more efficient, particularly in the dynamic sense of economic growth promotion. 
2. Policy Indicators. In order to implement the principles of market-oriented reforms in the tax system, some policy changes must be undertaken. They broadly fall into three components, from which various policy indicators can be derived (see Shome 1992). The first component deals with the structure of tax rates. Market oriented-reform usually implies a reduction of marginal rates in all categories of taxes, that is, income (both personal and corporate), property, and indirect (sales, excise, and value-added) taxes. Naturally, it is conceivable that marginal rates could be too low and that reforming the system would require increasing the rates. However, this situation would be rare as the status of unreformed economies is one of excessive government participation and tax burden. An important related question is how low tax rates should be. In theory, the optimal tax rate is where the marginal productivity of tax-financed public goods just compensates for the marginal tax burden on the economy's net rate of return (see Barro and Sala-i-Martin 1992). Therefore, the calculation of optimal tax rates should be country-specific and depend on the productivity of public goods and the rates of return of alternative private investment opportunities. It should also consider the likelihood of tax evasion and informality, consideration which tends to decrease the optimal tax rate.

Market-oriented reform also includes a reduction in the dispersion of tax rates and the explicit elimination of preferential or discriminatory treatment across sectors or goods. It is always possible to defend, on market-failure grounds, a discriminatory tax regime. However, as a rule, the burden of the proof for market-failure should be on the government's side, which in practice produces the implementation of a very limited number of discriminatory or preferential rates.

The second component of policy changes in tax reform deals with the type of taxation, namely, taxable sectors and activities. Market-oriented reforms in the tax system involve de-emphasizing steeply progressive rate structures of income and property taxes and reducing the tax burden on export and import sectors. This is compensated by a stronger emphasis on broadly based, low-rate taxes on domestic production, such as the value added tax (VAT). Apart from the economic efficiency reasons given above, this shift in the type of taxation is advocated on the grounds of collection efficiency, which is a major constraint in most developing countries. 
Finally, the third component of tax reform consists of strengthening the tax administration. This involves the creation of a tax-collection agency with the clear mandate of enforcing tax laws, with enough resources to implement its supervisory role (which includes a well-remunerated bureaucracy), with stiff penalties for corruption and capture of tax officials, and with sufficient coordination with the judicial system in enforcing the law.

\section{Outcome Indicators.}

There is a wealth of outcome indicators on tax reform. With enough diligence, we can obtain precise indicators related to each policy reform. Here we consider only three of them that are readily available and that broadly capture the main purposes of tax reform. The first is the ratio of tax revenues to GDP, which measures the success in raising revenues through non-inflationary means. The second is the ratio of international trade taxes to total tax revenues, which represents the reliance on a common type of distortionary taxation. The third is the VAT revenue productivity rate, which measures the comprehensiveness of the VAT and the strength of the tax administration.

The ratio of tax revenue to GDP signals government's reliance on taxes to finance its expenditures as opposed to debt accumulation, money creation, or transfers from public enterprises. Paradoxically, while a policy indicator of tax reform is the reduction of tax rates, it is generally the case that as result of tax reform the ratio of tax revenues to GDP increases. The change in the structure of taxation, the reduction in rates, and the strengthening of the tax administration can lead to sharp reductions in informality and tax evasion. Although the first impact of tax reform on the revenue ratio is positive, we cannot say that it is desirable that the ratio keeps increasing. There is in principle an optimal tax ratio to which tax reform should lead. The ideal indicator is, therefore, the difference between actual and optimal tax ratios, as defined above.

The ratio of international trade taxes to total tax revenue reveals the reliance on a common type of distortionary taxation. As argued above, one characteristic of unreformed countries is that they heavily tax the most easily monitored sectors, of which international trade is a prime example. Not surprisingly, the share of export and import taxes in total revenues is large in most developing countries; however, as they reform and develop, international trade taxes represent a decreasing share of tax revenues. This 
development is even more remarkable when we consider that the volume of exports and imports increases considerably as result of international trade reforms.

Lastly, the productivity rate of the value-added tax measures not only the effectiveness of the VAT --the centerpiece of tax reform in many countries-- but also the comprehensiveness and enforcement of the whole tax system (see Silvani and Brondolo 1994 for concepts and data on VAT productivity for several developing and industrial countries). In a context of fragile tax administration, the VAT with its self-monitoring feature, has become the best option for revenue generation with limited distortions. Its achievements as a revenue generator have allowed the easing of the tax burden on the formal corporate sector and the reduction of trade tax rates. The VAT productivity rate, defined as the ratio of the share of VAT revenues in GDP to the average VAT rate, contains information on two aspects of the VAT system. The first is the coverage of the VAT, that is, the extent to which national expenditures are taxable. The elimination of

preferential treatments to certain areas (e.g., agricultural products) and the inclusion of all types of goods and services at different points in the production ladder imply an increase in the VAT base, which ceteris paribus leads to an increase in the ratio of VAT revenues to GDP. The second aspect reflected by the VAT productivity rate is the strength and efficacy of the tax administration in preventing tax evasion. Holding constant the VAT base, an improvement in tax enforcement should expand the ratio of VAT revenues to GDP, in relation to the VAT rate. A related indicator that more directly focuses on tax enforcement is the rate of VAT compliance (or the inverse of evasion). This can be constructed as a variation of the VAT productivity rate; specifically, the rate of VAT compliance is the ratio of the share of VAT revenues in the VAT base relative to the VAT rate (where a value of 1 indicates perfect compliance).

\section{F. PUBLIC INFRASTRUCTURE AND PUBLIC FIRMS}

1. General Principles. Government participation in productive activities should be separated in two categories: provision of infrastructure and production of goods and services. While in the former the government provides goods that are complimentary to private sector activities, in the latter state-owned enterprises (SOE) replace or compete directly with private firms. Economic theory and empirical evidence suggest that, in the absence of market failures, there is virtually no justification for the government to engage 
in the production of goods and services. Even when market distortions are present, regulations can provide incentives for private firms to operate in a socially optimal manner. Reforms of infrastructure sectors have, thus, three main objectives. First, divesting SOEs in areas where private sector activities are efficient. Second, increasing efficiency in the production of those goods and services that are delivered by the government. Third, reducing -better, eliminate- the budgetary burden faced by governments.

\section{State-owned enterprises}

In competitive markets, governments have justified the creation of SOEs on the basis of lack of private sector interest or on infant-industry considerations. In fact, lack of interest was usually the result of government interventions and distortions in other markets, such as the financial sector (World Bank, 1995). Infant-industry policies, on the other hand, had been generally unsuccessful and quite costly (Noland and Pack, 2002). Hence, governments should not get involved in the provision of goods and services that can be better provided by the private sector under adequate regulation. Reforms include deregulation, privatization, and divestiture as their main tools.

In the presence of market failures, governments justified the creation of SOEs on the basis that public sector managers can more easily control externalities, exploit scale economies, or operate firms at socially optimal levels. This led to the proliferation of SOEs as natural monopolies. Evidence concludes, however, that public firms are typically inefficient because they operate as monopolies, managers are subject to poor incentive mechanisms, and governments often intervene in their operation to fulfill political goals (World Bank, 1995). As a result, SOEs absorb large amounts of funds that could be best spent on social services and often capture a disproportionate share of credit, squeezing out private sector borrowing. Moreover, since monitoring and control is typically softer within the government, SOEs tend to create more externalities and social costs (e.g., state-owned factories often pollute more than privately owned plants). Privatization and divestiture have also been proposed for SOEs in imperfect markets. Technological breakthroughs challenged the existence of natural monopolies in telecommunications, energy, and transport, thus giving private entrepreneurs the right to compete with incumbents. Whenever governments prefer to keep certain firms in state 
hands, reforms should deal with their inefficiencies, so as to free resources for other, socially more relevant, uses.

\section{Infrastructure}

A vast empirical literature suggests that differences in infrastructure may be responsible for substantial differences in economic growth and welfare (e.g., Calderón et al., 2002). Developing countries, on average, show a very poor record in building and maintaining infrastructure. Demand for public infrastructure services is greatly distorted by cross-subsidies and artificially low prices that bear little relation to costs (World Bank, 1994). The distortions in prices and output, the heavy influence of government on what ought to be exclusively commercial decisions, and the decay of networks, have all worked to create an environment ripe for mismanagement and corruption.

The successful experience of some countries -such as the UK or Chile- with deregulation and franchising of telecommunications, roads, and energy indicates that reforms should aim at creating competition where possible. In those sectors where competition is deemed impractical (e.g., natural monopolies with substantial informational asymmetries), reforms should set up strong, independent, economic regulation. If successful, these reforms will create an environment conducive to private sector participation, providing incentives to strive for efficiency savings that can ultimately be passed on to consumers and for the expansion in the provision of services. Nevertheless, reforms in this area run the risk of failing either by incompetence in design or implementation or, most typically, when regulated firms are able to "capture" the authorities to set the regulation to their advantage. The risk of state capture increases with the weakness of the institutional framework (see section $\mathrm{H}$ ) and the lack of political will to regulate markets when necessary.

\section{Policy indicators.}

\section{State-owned enterprises}

The main reform instrument for SOEs has been privatization, for which indicators beyond the obvious are difficult to find. The standard indicator is the total proceeds of

privatization, usually expressed in absolute terms (millions of US\$). Clearly, this indicator requires a scale measure to be meaningful. In principle, one would like to scale proceeds using public sector wealth, which is unavailable. As a second best we suggest 
expressing proceeds either as a share of GDP or value added generated by public firms. It is customary to use aggregate figures for macroeconomic analysis, but this masks the important effects of privatization at the sectoral level. For this reason, the analysis ought to be extended to include indicators at the sectoral levels in order to gain precision with regard to the impact of privatization in the working of different areas of the economy. In particular, efficiency measures at the firm and industry levels --such as productivity gains and service quality-- must be included in the analysis to avoid misleading evaluations. In some economies, the authorities may have tried to maximize the proceeds from privatization (for fiscal purposes), even at the cost of creating less competitive markets. In these cases, the benefits generated by higher levels of efficiency will not be transferred to consumers in the form of reduced relative prices.

For firms remaining in state hands, reforms focus on two elements. First, enacting measures to eliminate transfers from the central government to cover operating deficits, hardening budgetary procedures, and increasing accountability. Reforms in several countries forbid by law the financing of SOEs deficits. Second, introducing incentives to improve on management and efficiency and expand coverage, when necessary. This includes restructuring (outsourcing, streamlining procedures, performance incentives for managers, eliminating redundant labor, and re-capitalizing firms), increased competition (allowing entry of private firms and deregulating prices), and enacting a wide array of corporate governance regulations. Broadman and Recanatini (2000) provide an indicator for the latter based on (i) the introduction of a company law that provides for effective boards of directors and share ownership disclosure requirements; (ii) the establishment of strong penalties for insider trading and pyramid schemes; (iii) the appointment of 'outsiders' (non-managers) to boards of directors and the introduction of staggered elections of directors; (iv) the establishment of an effective legal framework for the exercise of creditors' rights; and (v) the introduction of published independent audits of financial accounts and credit rating agencies.

\section{Infrastructure}

Reforms comprise three categories that apply equally to private and public firms.

First, applying commercial principles to the management of infrastructure firms or facilities. A key component in this case is pricing reform, which we discuss below. 
Second, introducing competition into a sector or removing barriers to entry so that contestability is a real option. Whenever sectors conform natural monopolies, reforms should implement regulation of quality, pricing, and access under the tutelage of an independent regulatory agency. Third, involving users and stakeholders in the project design and operation of infrastructure facilities.

The depth of pricing reforms can be assessed using as policy indicator the operating losses incurred by firms (as percent of sales or the capital stock), excluding transfers from the government. Consistent with the reduction in price distortions, a number of countries have eliminated implicit cross-subsidies among different sectors. Instead, they rely on setting prices in line with costs and subsidizing those in need with strictly targeted policies (e.g., access to potable water and sanitation). The degree of cross-subsidization can also be used as an indicator of reforms.

Wherever competition is feasible in infrastructure sectors, divestiture (either in the form of privatization or franchising) can be measured by the share of public firms in value added, providing a simple yet indicative measure of the reforms. For sectors that conform natural monopolies, reforms can be assessed be divestiture measures but must include also the implementation of regulatory frameworks that effectively separate the government from the operation of the business and set explicit, verifiable targets for investment, efficiency gains, service coverage, and quality.

\section{Outcome indicators}

\section{State-owned enterprises}

A widely used indicator of the degree of privatization is the share of public firms in value added and employment. Aggregate figures, again, mask the effects of privatization at the industry level, which suggests the need to include sectoral indicators, in particular in energy or telecommunications. A second indicator is the change in transfers from the central government or state banks to firms. Successful reforms should induce sharp reductions in financial and operating losses and, thus, in government transfers (Megginson and Netter, 2001). An indirect indicator of privatization is the change in foreign direct investment (FDI), because in several countries, privatization has been coupled with FDI liberalization. We suggest using FDI in privatized firms as a measure of reform outcomes, either in absolute value terms or as a percentage of value 
added. Foreign portfolio investment can also be used (reflecting capitalization), but the association is arguably looser.

Indicators of improved management for non-divested SOEs focus on profitability and efficiency. Measuring profitability is relatively straightforward, as the difference between earnings and total operating costs. Interpretation should be cautious because, for several reasons (distributive justice, political constraints), SOEs may be required only to recover costs and not to generate profits. The customary indicators of efficiency are average labor productivity, defined as value added divided by employment. An indirect measure of increased efficiency is the observed reduction in relative prices for goods and services (e.g., lower tariffs) or quality improvements (e.g., shorter waiting lists).

\section{Infrastructure}

Measuring the outcome of the reforms in infrastructure use the same set of indicators for public firms. As documented in World Bank (1994), these indicators capture the dramatic changes in efficiency and profitability as a result of reforms in telecommunications, transport, water provision, and electricity in several developing economies. Indicators of the impact of reforms in the availability of infrastructure typically consider measures such as kilometers of roads, kilometers of railway lines, number of telephones, electricity generating capacity, access to potable water and sewerage, irrigation and waste disposal (see Canning, 1998). These indicators can be supplemented with some measures of infrastructure quality to provide a richer assessment of the reforms (e.g., percentage of roads in poor condition, percentage of local phone calls that are unsuccessful, percentage of availability of diesel locomotives, and percentage of electricity lost from the system).

\section{G. LEGAL AND REGULATORY FRAMEWORK}

1. General Principles. The legal and regulatory framework comprises the laws, regulations, and legal institutions needed to facilitate dynamic economic development and environmental protection in a decentralized economy. In the absence of market failures, unregulated private initiative leads to the creation and exploitation of profitable opportunities through market activities. The legal framework should provide the basic institutions for a minimum-cost operation of the market, including the protection of property rights, the provision of expedite conflict resolution mechanisms, and the 
capacities to enforce contracts. Market power, asymmetric information, and externalities, nevertheless, do exist and can hamper the performance of the private sector unless an efficient and adequate regulatory framework is in place. Regulations should counter market imperfections so that private firms lead to investment, innovation, and sustained growth.

Regulation is a public good that is usually not well provided by the private sector. As such, it is the responsibility of the governments to enact regulatory frameworks for the different regulated industries and enforce their applications. A general prescription in this regard is the separation of regulatory agencies from enforcement units to add transparency and credibility to the regulatory process. As discussed in section $\mathrm{H}$, nevertheless, setting up these agencies and providing incentives to the staff to operate efficiently and honestly usually requires good governance practices that themselves call for additional reforms in the State.

Traditionally, economic literature identified numerous market failures and suggested, as a general prescription, that tight regulation was required to avoid socially inefficient outcomes (Stigler, 1971). Often, governments reserved entire areas of the economy to be developed exclusively by public firms (e.g., natural monopolies and strategic industries). This "public interest" approach to regulation, however, requires key elements that are actually absent in most developing economies. First, it assumes that the cost of enforcing regulations is small and does not affect the efficiency of the economy. Second, it assumes that public firms operate in a socially efficient manner. Third, it assumes that managers of regulated firms and regulators cannot use regulation in their own benefit.

In most countries, however, excessive and often arbitrary regulation suffocated private initiatives, leading to low investment and insufficient innovation. Public firms did not compete on fair grounds with the private sector since they benefited from ample government transfers to cover losses (World Bank, 1995). Consequently, first generation reforms aimed at deregulating markets, reducing the cost of doing business for private firms, reducing the regulatory uncertainty and arbitrariness, and avoiding discriminatory practices among firms or sectors that lead to inefficiency and rent-seeking behavior. In countries where reforms were successfully implemented there was a strengthening in the 
protection of property rights -legally or de facto- with the withdrawal of the public sector, and in the capacity to enforce contracts.

First generation reforms allowed substantial private sector participation and investment. The outcomes in terms of increased efficiency, innovation, and enhanced consumer welfare have been somewhat mixed. Second-generation reforms stem from the growing awareness that first generation reforms were necessary but not sufficient to enhance growth and that many governments failed in providing adequate guidelines to guarantee proper functioning of a market economy.

Criticisms focus on both the legal and regulatory frameworks. Legal systems are deemed too slow and their sentencing too unpredictable to become the powerful signal needed by private firms to operate efficiently. Likewise, they do not necessarily provide expedite and affordable conflict resolution mechanisms for private sector disputes (Basañes and Willig, 2002). One explanation for the observed reluctance to modify legal frameworks is that reforms are very expensive, something wealthy nations often do not realize because the relative cost of the institutions that secure the rule of law is small (Posner, 2002). Another is that a revamped legal system may also enforce bad laws that reduce economic efficiency. A third explanation is that there are informal substitutes for the legal enforcement and protection of property and contract rights, including arbitration (with or without the legal enforcement of the arbitrator's judgment), reputation, and strong-arm tactics, such as those used in illegal markets.

Regulatory frameworks, on the other hand, have been criticized on the grounds that they induce a high cost of doing business and, in particular, that firm entry and exit are poorly designed, leading to non-competitive environments. Studies in the "public choice" literature provide evidence that regulated firms can affect the regulatory process to avoid entry and exact rents, capturing regulators to their advantage (La Porta et al., 2002). Moreover, politicians can implement entry regulations in order to extract rents from firms, and ultimately consumers (de Soto, 1990). Exit costs (e.g., bankruptcy procedures) can be equally important in increasing market power and reducing efficiency. Since economic activity is a risky project, inevitably some initiatives will not prosper. In such cases, society needs to move resources from failed businesses to more profitable activities. The legal framework should be designed to make bankruptcy procedures 
simple and inexpensive, so that resource relocation is accomplished swiftly while, at the same time, protecting the rights of creditors and workers. There are, at least, two compelling reasons to focus on exit costs as an important component of economic reforms. First, failed businesses use resources (such as labor and capital) that earn a low return from a social point of view, thus reducing general productivity. Second, bankrupt firms that do not exit the market (e.g., when losses are passed on to consumers or absorbed by the government) have little incentives to improve productivity. At the same time, they block the entry of new and more efficient producers to the market thus reducing lower productivity gains in the long run (Bergeoing et al., 2002).

The analysis of reforms to legal and regulatory frameworks is only meaningful when considered in connection with other reforms. Foreign trade liberalization and governance reforms enhance the capacity of the government to provide the adequate environment for economic development. Labor regulations have important effects on entry and exit and the adoption of technology. Trade liberalization provides discipline to imperfect markets even when specific regulations to curtail market power have not been implemented.

2. Policy Indicators. Unambiguous, objective measures of the quality of legal and regulatory frameworks are very hard to find. Direct reporting by experts and firms on the main constraints to enterprise development can be a valuable tool for assessing the business climate in an economy, notwithstanding the element of subjectivity and margins of errors.

Deregulation of potentially competitive markets was the most important of the early reforms. Policies included the elimination of production quotas and price controls, the liberalization of wages and labor market restrictions, and opening markets to the private sector. Standard indicators of deregulation are the number of prices directly controlled by the government, the share of production that is to be sold under quota restrictions (as \% of GDP), and the number of goods that require licensing from the government to be marketed.

Second-generation reforms focus mainly on market entry and exit, and the conditions in which private firms compete. Djankov et al. (2002a) suggest using three indicators of entry conditions: the number of procedures that firms must go through, the 
official time required to complete the process, and its official cost. Substantial empirical evidence suggests that more procedures and longer delays reflect bribe extraction and/or capture (make entry less attractive to potential competitors). Predictions regarding the cost indicator are ambiguous. A benevolent social planner may finance screening of market entrants from direct fees, thus rendering the latter as an imperfect measure of costs. On the other hand, higher fees are frequently used to deter entry. Indicators of the reforms in exit conditions would include, at least, the legal reform of bankruptcy procedures, a measure of efficiency of the bankruptcy agencies and officers, and its average cost (e.g., annual number of sentences as shares of filings, time required and official costs to sentence). The World Bank is assembling an index of the efficiency of the bankruptcy process, based on the procedures for filing, the petition hearing, the court's decision, the appointment of an insolvency practitioner, the assessment of claims and their ordering by priority, and the sale of assets.

Assessing the impact of reforms on the efficiency of the judiciary system for civil procedures is quite difficult. Djankov et al. (2002b) develop indicators based on the analysis by law firms of two specific legal procedures (the eviction of non-paying tenants and the collection of a bounced check). A measure of the reforms would be the change in the average time and the monetary cost involved in accomplishing each goal. In similar fashion, three indicators of contract enforcement are the number of independent procedural steps counted from the moment the lawsuit is filed in court until the contract is fulfilled; the associated time of the procedures; and their cost as a percentage of GNP.

3. Outcome indicators. Evaluating the impact of changes in legal and regulatory frameworks is difficult because of the microeconomic, specific nature of most reforms and also because changes occur slowly due to the presence of substantial adjustment costs. Hence, it is necessary to focus on intermediate measures of the impact of reforms. If new regulations are better, it should be first noticed in price-quality improvements, either as unit-cost reductions (and lower relative prices) for same-quality goods or, alternatively, quality improvements with constant unit costs. A second measure often used is the reduction in excess capacity of firms operating in a particular market, a result of improved management capabilities or better market access. A third suggested measure 
is the reduction in queuing time for consumers in better-regulated markets (e.g., months of wait to obtain a telephone line or water connection).

Beyond price-quality improvements, production-related measures provide an indirect, yet readily available, assessment of the outcomes of reforms. First, changes in average labor productivity at the firm level (defined as value of production per hour worked), although interpretation should be careful as productivity also responds to changes in relative prices. Second, changes in TFP defined as the Solow residual (value added less the cost of capital services and manpower). Third, change in use of factors (capital, intermediate resources and manpower), in particular investment. See Galal et al. (1994).

To the extent that entry and exit reforms have impact on market structure, indicators of the impact of reforms can be derived from changes in the structure of the different sectors. Successful entry/exit reforms should lead to declining plant age (new firms should displace old, inefficient firms), technological upgrading (measured by purchases of licenses and investment in technology), relocation of production within industries (from less efficient to higher productivity firms), product and market diversification, and declines in unit costs for goods in deregulated markets (Bergeoing et al. 2003).

\section{H. GOVERNANCE}

1. General Principles. A growing body of literature points to the importance of governance in originating and implementing welfare-enhancing economic policies (Kaufman et al., 1999). The state can potentially provide the private sector with an environment in which property rights are respected; legal contracts are enforced; and government regulations counter market imperfections. While adequate policies are essential, successful reform implementation requires a government with the ability to execute them efficiently and credibly. Without governance, it is difficult to set up or maintain a policy environment that is conducive to economic growth.

Good governance is based on five principles that provide the direction of reforms and suggest the choice of its indicators. First, good governance depends on credibility: governments that build strong ethics reputation are able to reduce pervasive problems 
such as conflicts of interest, corruption, lobbying, and regulatory capture. Second, good governance relies on adopting clear and simple rules and implementing effective enforcement mechanisms. Reducing the risk that governments will change the rules of the market or will apply regulations to benefit incumbents is critical to investment and, hence, to growth and welfare. In countries with weak legal traditions, simple rules place fewer demands on courts, are cheaper and more likely to be accurate, and reduce the risk of corruption.

These high responsibilities for government can be achieved only when the public administration behaves both honestly and efficiently (see discussion below). Consequently, a third key principle of good governance is transparency. It reduces the scope for regulatory failures (such as capture and bias), increases accountability, and reduces market uncertainty. Fourth, good governance requires strong mechanisms of checks and balances by consumers, competition authorities, courts, and parliaments. Transparency and accountability provide incentives to reduce corruption. Corruption in government, especially of officials with decision making power, is detrimental to social welfare because it makes the state pursue public policies and programs that benefit certain groups rather than society in general and because it encourages wasteful rent-seeking activities. Corruption is mostly due to lack of both proper monitoring and clear accountability rules; and it is compounded by lack of procedural clarity, complexity of bureaucratic requirements, and imposition of overly restrictive regulations.

Finally, the quality of the civil service is the fifth crucial principle for governance. To a large extent, good governance depends on having an efficient, motivated, and effective civil service. The efficiency of public goods provided by the government depends largely on the size and quality of the public workforce and on the institutional rules which guide its behavior. As discussed by Schiavo-Campo et al. (1997) some reforms may not require administrative capacity (e.g., removing price controls), but most others do depend critically upon having qualified personnel (e.g., enterprise restructuring). Fiscal policy is another reason to focus on the quality of the civil service. Expenditure management and tax administration are quite inefficient without a competent civil service. 
2. Policy Indicators. Governance reforms are very difficult to measure for several reasons. First, governance is largely an intangible asset. Second, it consists of a potentially large number of components that are difficult to measure individually (e.g., transparency, honesty, accountability). Third, these components affect the quality of governance in complicated manners, both directly and indirectly, individually and collectively. Most reforms discussed in other sections of this paper consider measures that improve governance. For example, trade liberalization eliminates incentives to corruption derived from cumbersome protection schemes and privatization reduces the scope for rent-seeking and lobbying. Similarly, privatization can greatly reduce the scope for rent seeking and lobbying when regulation is correctly designed and effectively enforced.

One reform that relates directly to the workings of the government is the "rightsizing" of public employees. Civil service reform can improve transparency, accountability and honesty, enhancing the credibility of policies. It usually includes two types of measures. First, eliminating over-staffing, arising from inefficient management, political interference (e.g., appointment of personnel to pay political favors), and lobby from unions. An obvious, yet gross, indicator of the reforms is the reduction in the share of public employment in total employment. The measure can be refined to exclude employment in SOE and concentrate in the central or general government. Second, implementing and enforcing meritocractic recruitment systems. Qualitative indicators of reforms include the enactment of formal mechanisms to allow entry into government service conditional upon pre-specified requisites (passage of a civil service exam or attainment of formal education degrees), the setup of proper procedures of internal promotion (requesting that higher-level agency positions be filled by current agency employees, members of the civil service, or sufficiently accredited professionals), and implementation and maintenance of competitive salaries, tightly related to effort. Elimination of ethnic-based quotas is also an important component of successful reforms, although they usually require substantial political negotiations.

Considerable effort and expenditure have been utilized to reform bureaucratic dysfunctions such as red tape, organizations that only communicate in vertical lines, are distant from those they serve, are split into too many hierarchical levels, are 
unsympathetic to their clientele, and lack flexibility (Turner, 1999). The implementation of private sector management techniques appears to be an important tool to align incentives within the government. Reforms along these lines include implementing performance indicators, benchmarking, and total quality management.

Decentralization is another reform that could potentially improve credibility and governance. Decentralization can lead to greater variety in the provision of public goods, tailored to suit local populations (Tiebout, 1956). Besley and Coate (2000) assert that another benefit from decentralization is the improved accountability of bureaucrats. A measure of the degree of decentralization proposed by Fisman and Gatti (2000) is the sub-national share of total government spending. A higher share would suggest a more decentralized public sector and, presumably, better governance. Nevertheless, there is no consensus that decentralization is unequivocally good for a country. There are political economy considerations, mostly related to the distribution of fiscal revenues and liabilities, that raise doubts on whether decentralization can lead to more efficient, market-oriented outcomes for government action.

Finally, Beck et al. (2001) provide a measure of reforms in "checks and balances", using as indicator the number of decision makers whose agreement is necessary before policies can be changed. Numerous decision makers with different policy preferences are likely to respond differently to reform opportunities than single decision makers. On the other hand, multiple decision makers may offer greater protection from arbitrary government action to individuals and minorities.

3. Outcome Indicators. When analyzing the success of public policies, it is quite difficult to isolate the contribution of good governance. There is, however, the possibility of assessing changes in the quality of public institutions and services by the way they are perceived by businessmen and economic and political consultants, who deal with various government branches on a daily basis. These subjective indicators are collected by a handful of international agencies, namely Business International (BI), the International Country Risk Guide (ICRG), and Business Environmental Risk Intelligence (BERI). Indicators include, among others, indices for corruption, bureaucracy and red tape, rule of law, the likelihood of changes in government, political instability, expropriation risk, and repudiation of contracts by government. Indicators are usually used to generate composite 
indices representing the different impacts of governance: for example, Mauro (1995) use these measures to create an index of governance instability while Knack and Keefer (1995) select some indicators as being of greatest relevance to the security of private property and the enforceability of contracts.

Expanding on surveys designed and implemented by Brunetti, Kisunko and Weder (1997), the World Business Environment Survey (WBES) of the World Bank surveys firms in more than 75 countries, inquiring about corruption, the quality of government-provided services, and the predictability of laws and policies. Kaufmann et al. (1999) provide a methodology for constructing indices of perceptions on corruption, by aggregating governance indicators from numerous sources including surveys of enterprises and households.

These subjective governance indicators have attained wide usage in the growth and development literature. Its application when discussing the impact of reforms, however, should be very careful. First, ratings may be affected by the expert's knowledge of recent economic performance. Second, these measures typically represent conditions facing foreign or large investors, not necessarily those confronting most domestic investors. Subjective risk evaluations remain only partial indicators of the institutional environment that can affect economic performance.

An alternative to subjective ratings was proposed by Clague et al. (1999). They suggest using the proportion of M2 within the banking system, an objective measure not subject to contamination by the expectations of surveyed country experts. The justification for this measure is that individuals will hold a larger proportion of their financial assets in the form of currency in environments where third-party enforcement of contracts is unreliable. Money lent to financial institutions (i.e. bank deposits) is less safe where contracts cannot be relied upon. The ratio will increase where governments better enforce and respect contracts and private property rights. The main limitation of the CIM is that, at best, it only measures the tradeoff between holding assets in currency or bank deposits. Moreover, other elements affect this decision rendering its comparability across countries dubious (e.g., inflation). 


\section{CONCLUSIONS}

In the last two decades most developing economies have engaged in marketoriented reforms. The defining guidelines underlying these reforms are private participation, competition among private agents, and a change in the role of the government with respect to economic activity. In general, reforms imply reducing government participation and market interference. In such cases, the instruments of reforms are typically price liberalization, market deregulation and privatization. In some cases, markets require government intervention precisely to encourage competition. This occurs when markets fail due to asymmetries of information, moral hazard, or natural monopoly. Market-oriented government participation takes the form of enacting regulatory frameworks and providing mechanisms to enforce regulations and contracts. This paper presents ways of measuring the progress of market-oriented reforms in various policy areas from the perspective of both policy and outcome indicators. The policy areas we cover include not only those of traditional, first generation reform but also the areas related to institutional and legal reform.

As a final point, we should discuss an important caveat to our analysis, already mentioned in the introduction. Market-oriented economic reform should best be understood as a multi-faceted process. Although for analytical reasons we have treated various areas separately, economic reforms in each of them are interconnected. First, they follow the same underlying principle of competitive private participation. Second, the implementation of a reform in one area often requires corresponding changes in another. For instance, a reduction and homogenization of tariff rates requires restructuring the domestic tax system. Third, the success of economic reform in one area often depends on complementary reforms in other areas. For instance, in order for trade openness to lead to export growth and a more efficient domestic industry, labor markets must be flexible; otherwise, as some people claim, trade openness could just "kill" domestic firms.

Although it is clear that economic reforms require and complement each other, it is less clear what the sequencing should be (from a normative perspective) or can be (from a positive, practical perspective). For example, on the one hand it would be ideal to have a properly working domestic financial system prior to opening to international 
capital flows; on the other hand, however, without the incentives created by international financial liberalization, domestic financial markets may not be improved. In the case of economic reform, we know that the whole is more than the sum of its parts; however, we are less certain as to whether the process should be balanced across reforms or whether some of them must take the lead. Measurement issues dealing with the complementarity and sequencing of market-oriented reforms remain an important but relatively unexplored area of research. 


\section{REFERENCES}

Basañes, F. and R. Willig (2002): Second-Generation Reforms in Infrastructure Services. Inter-American Development Bank.

Beck, T., R. Levine and A. Demirgüç-Kunt. 2000. "A New Database on Financial Development and Structure." The World Bank Economic Review Vol. 14 No. 3.

Beck, T. G. Clarke, A. Groff, P. Keefer and P. Walsh (2001). "New Tools in Comparative Political Economy: The Database on Political Institutions." World Bank Economic Review 15(1): 165-76.

Bergoeing, R.; A. Repetto and R. Soto (2003). "Plant Dynamics in Chile", mimeo, Instituto de Economía, Pontificia Univesidad Católica de Chile.

Besley, T. and S. Coate (2000): "Centralized versus Decentralized Provision of Local Public Goods: a Political Economy Analysis", CEPR Working Paper 2495.

Brunnetti, A., G. Kisunko and B. Weder (1997). "Institutional Obstacles of Doing Business: Region by Region Results From a Worldwide Survey of the Private Sector.” World Bank Policy Research Working Paper No. 1759.

Caballero, R. (2002). "Coping with Chile's External Vulnerability: a Financial Problem." Economic Growth: Sources, Trends, and Cycles. Edited by N. Loayza and R. Soto. Central Bank of Chile.

Calderón, C., W. Easterly and L. Servén (2002). "Infrastructure Compression and Public Sector Solvency in Latin America." Central Bank of Chile Working Paper No. 187.

Canning, D. (1998). “A Database on World Infrastructure Stocks: 1950-1995," World Bank Working Paper Series \#1929.

Caprio, G., J. Barth and R. Levine. 2001. "The Regulation and Supervision of Banks Around the World: A New Database ." University of Minnesota Financial Studies Working Paper No. 0006.

Caprio, G. and D. Klingebiel. 1996. "Bank Insolvencies: Cross-Country Experience." The World Bank Policy Research Working Paper No. 1620.

Clague, C.; P. Keefer, S. Knack, and M. Olson (1999). "Contract-Intensive Money." Journal of Economic Growth 4(2):185-211.

De Soto, H. (1990). The Other Path.

Djankov, Simeon, Rafael La Porta, Florencio Lopez-de-Silanes, and Andrei Shleifer, (2002a). "The Regulation of Entry," Quarterly Journal of Economics 117(1), $1-37$.

Djankov, Simeon, Rafael La Porta, Florencio Lopez-de-Silanes, and Andrei Shleifer, (2002b), "Courts: The Lex Mundi Project," Harvard Institute of Economic Research Paper \#1951.

Djankov, Simeon, Rafael La Porta, Florencio Lopez de Silanes Andrei Shleifer, and Juan Carlos Botero (2003). "The Regulation of Labor." http://ssrn.com/abstract $=$ 408480.

Dollar, D. and A. Kraay (2001a). "Growth Is Good for the Poor." World Bank Policy Research Working Paper No. 2587.

Dollar, D. and A. Kraay. (2001b). "Trade, Growth and Poverty." World Bank Policy Research Working Paper No. 2615. 
Edwards, S. (1988). Exchange Rate Misalignment in Developing Countries. The Johns Hopkins University Press for the World Bank.

Elbadawi, I. and R. Soto (1997). "Real Exchange Rates and Macroeconomic Adjustment in Sub-Saharan Africa and Other Developing Countries." Journal of African Economies 6(3, Supplement): 74-120.

Fisman, R. and R. Gatti (2000). "Decentralization and Corruption: Evidence across Countries", Working Paper 2290, The World Bank.

Frankel, J. and D. Romer. (1999). "Does Trade Cause Growth?" American Economic Review, 89(3): 379-399.

Galal, A., L. Jones, P. Tandon, and I. Vogelsang (1994). Welfare Consequences of Selling Public Enterprises: An empirical analysis. Oxford University Press for the World Bank.

Goldstein, Morris, Graciela Kaminsky, and Carmen Reinhart (2000). Assessing Financial Vulnerability: An early warning system for emerging markets. Washington, D.C.: Institute for International Economics.

Hinkle, L. and P. Montiel. 1999. Exchange rate misalignment: Concepts and measurement for developing countries. Oxford and New York: Oxford University Press for the World Bank.

International Monetary Fund (2000). "Debt- and Reserve-Related Indicators of External Vulnerability." Prepared by the Policy Development and Review Department in consultation with other Departments. Mimeo.

International Monetary Fund. Annual Report on Exchange Arrangements and Exchange Restrictions. Washington, D.C.

Kaminsky, Graciela, Saul Lizondo, and Carmen Reinhart (1998). "Leading Indicators of Currency Crises." International Monetary Fund Staff Papers 45(1): 1-48.

Kaufman, D., A. Kraay and P. Zoido-Lobaton (1999). "Governance Matters." World Bank Policy Research Working Paper No. 2196.

Knack, S. (2002). Governance and Growth: Measurement and Evidence, mimeo, The World Bank.

Knack, S. and P. Keefer (1995). "Institutions and Economic Performance: Cross-Country Tests Using Alternative Institutional Measures." Economics and Politics, 7: 20727.

Kornai, J. (1999). "What the Change of System Does and Does Not Mean." Economic Systems Vol. 23 (2).

Kornai, J. (2000). “Ten Years After 'The Road to a Free Economy': The Author's SelfEvaluation." Economic Systems Vol. 24 (4).

Kraay, A., N. Loayza, L.Servén, and J. Ventura. 2000. "Country Porfolios." NBER Working Paper No. 7795.

Lane, P. and G. Milesi-Ferreti. 1999. "The External Wealth of Nations: Measures of Foreign Assets and Liabilities for Industrial and Developing Countries." IMF Working Paper 99/115.

Lindauer, D. (1988). "Government Pay and Employment Policies and Government Performance in Developing Economies", Washington DC, The World Bank, World Development Report 1988 Background Paper, WPS 42.

La Porta, R., F. López de Silanes, A. Shleifer and R. W. Vishny. 1998. "Law and Finance." The Journal of Political Economy Vol. 106 No. 6, pp. 1113-1155. 
Loayza, N. 1996. "The Economics of the Informal Sector: A Simple Model and Some Empirical Evidence From Latin America". Carnegie-Rochester Conference Series on Public Policy No. 45, pp 129-162.

Loayza, N. and L. Palacios. 1997. "Economic Reform and Progress in Latin America and the Caribbean." World Bank Policy Research Working Paper No. 1829.

Lora, E. 1997. "A Decade of Structural Reforms in Latin America: What Has Been Reformed and How to Measure It." Inter-American Development Bank Working Paper Green Series No. 348.

Mauro, P. (1995). "Corruption and Growth". Quarterly Journal of Economics Vol. 110, pp 681-712.

Megginson, William L. and Jeffrey M. Netter. "From State To Market: A Survey Of Empirical Studies On Privatization" Journal of Economic Literature 39 (June): 321-89.

Nash, J. and S. Andriamananjara. (1997) "Have Trade Policy Reforms Let to Greater Openness In Developing Countries?" Economic Reform and Progress In Latin America and the Caribbean." World Bank Working Paper Series No. 1730.

Noland, M. and H. Pack (2002). "Industrial Policies and Growth: Lessons from International Experience," in Economic Growth: Sources, Trends, and Cycles, N. Loayza and R. Soto, eds., Central Bank of Chile.

Organization for Economic Cooperation and Development. International Direct Investment by Country Vol. 2002 release 02.

Organization for Economic Cooperation and Development. International Direct Investment by Industrial Sector Vol. 2001 release 02.

Posner, R. (2002). "Creating a Legal Framework for Economic Development." The World Bank Research Observer Vol. 13 No. 1, pp 1-11.

Rama, M. and R. Artecona. 2000. "A Database of Labor-Market Indicators Across Countries." Unpublished manuscript, The World Bank Group.

Rauch, J. E. and P. B. Evans (2000). "Bureaucratic Structure and Economic Performance." Journal of Public Economics, 74, 49-71.

Rodrik, D. (1996). "Understanding Economic Policy Reform." Journal of Economic Literature Vol. 34 (1): 9-41.

Recanatini, Francesca and Harry G. Broadman (2000). "Seeds of Corruption: Do Market Institutions Matter?" World Bank Working Paper No. 2368.

Sachs, J. and A. Warner (1995). "Economic Reform and the Process of Global Integration," Brookings Papers on Economic Activity.

Schiavo-Campo, S.; G. de Tommaso, and A. Mukherjee (1997). An International Statistical Survey of Government Employment and Wages. Policy Research Working Paper No. 1806. The World Bank, August.

Shome, P. 1992. "Trends and Future Directions in Tax Policy Reform: A Latin American Perspective." Bulletin of the International Bureau of Fiscal Documentation, September.

Silvani, C. and J. Brondolo. 1994. "An Analysis of VAT Compliance." Fiscal Affairs Department, International Monetary Fund, Washington, D.C., November. Mimeograph.

Stigler, G. J. (1971). "The Theory of Economic Regulation." Bell Journal of Economics and Management Science Vol. 2 No. 1, pp 3-21. 
Tiebout, Charles (1956). “A Pure Theory of Local Expenditures," Journal of Political Economy, vol. 64, pp. 416-24.

Turner, M. (1999). "Public Sector Reforms and Institutional Renewal", mimeo, University of Canberra.

United Nations Conference on Trade and Development. The World Investment Report 2000: Cross-border Merger and Acquisitions and Development.

Williamson, J. (1993). “Exchange Rate Management.” Economic Journal 103(416): 18897

Williamson, J. (1995). "What Washington Means by Policy Reform." The International Political Economy and the Developing Countries Vol. 1: 514-28

Williamson, J. (2000). "Neoliberalism versus Neopopulism." Capital Markets, Growth, and Economic Policy in Latin America 171-75.

World Bank (1995). Bureaucrats in Business: The Economics and Politics of Government Ownership, Washington, D.C.: The World Bank.

World Bank (1994). Infrastructure for Development, Oxford University Press for the World Bank.

World Bank (1995). Bureaucrats in Business: The Economics and Politics of Government, Oxford University Press for the World Bank.

World Bank (2003). Doing Business in 2004: Understanding Regulation. Oxford University Press for the World Bank. 


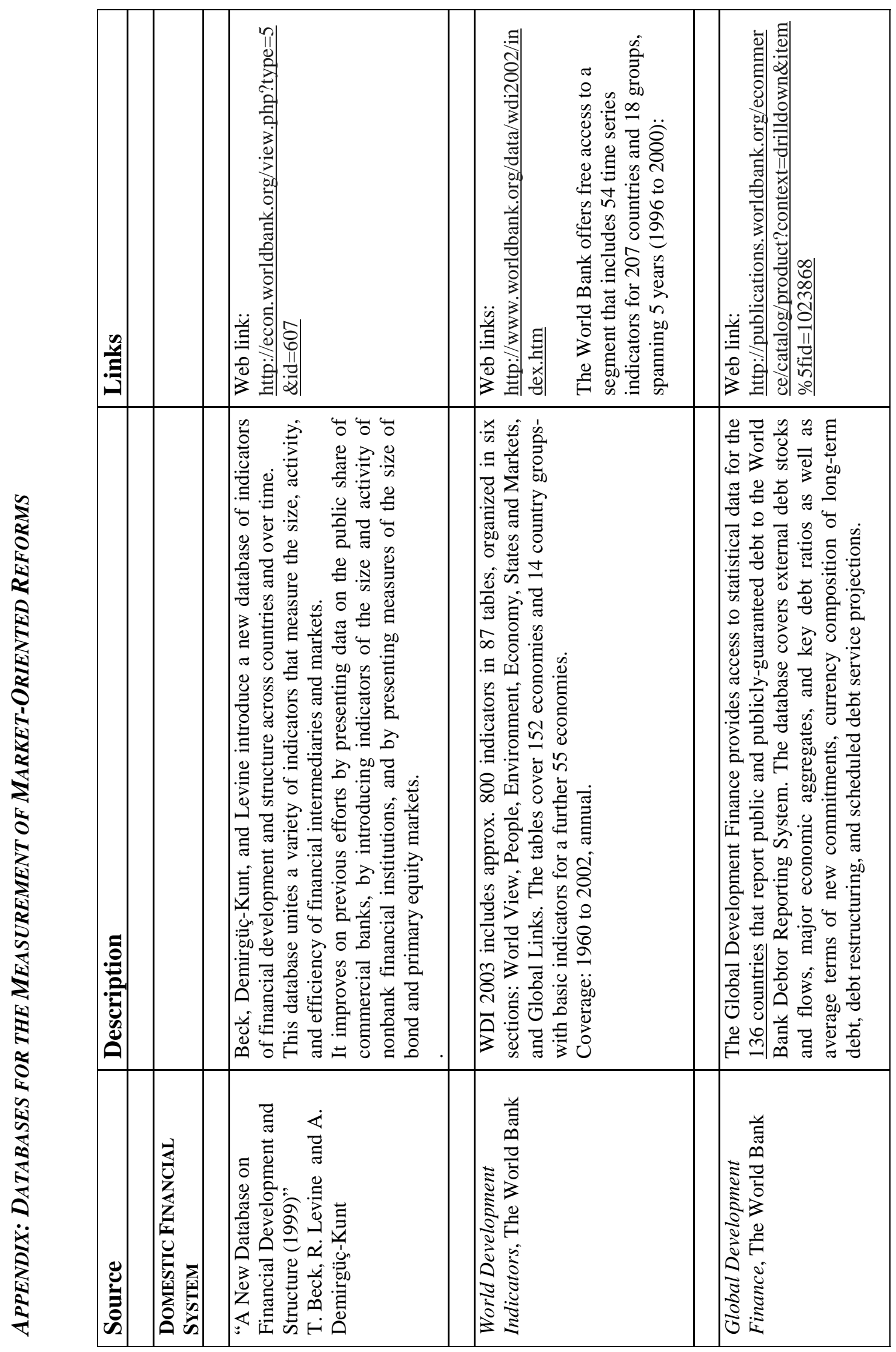




\begin{tabular}{|c|c|c|c|c|}
\hline$\frac{\Omega}{3}$ & 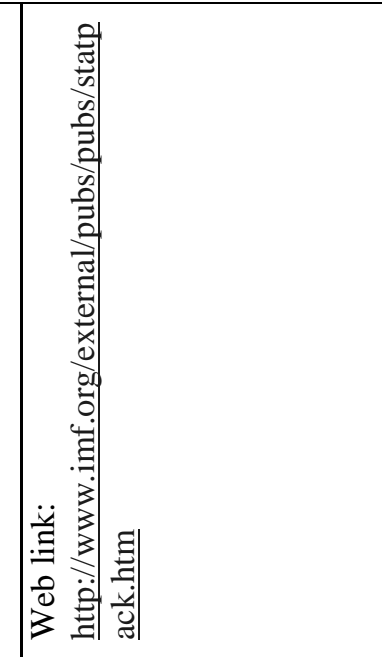 & 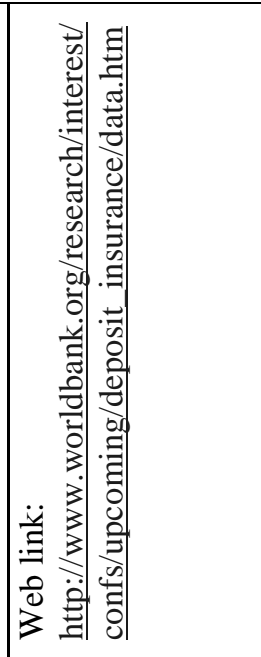 & & 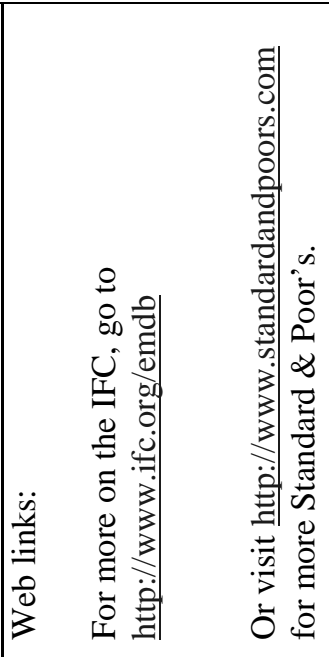 \\
\hline 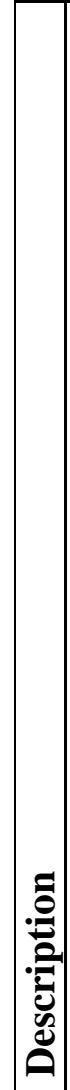 & 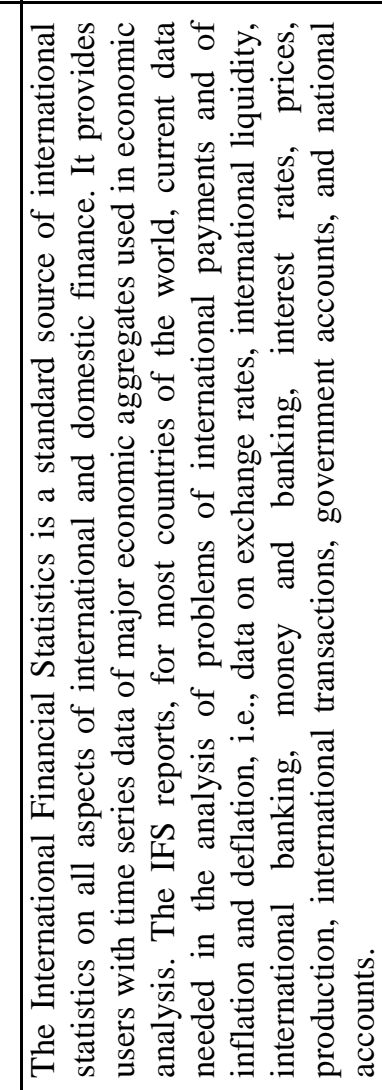 & 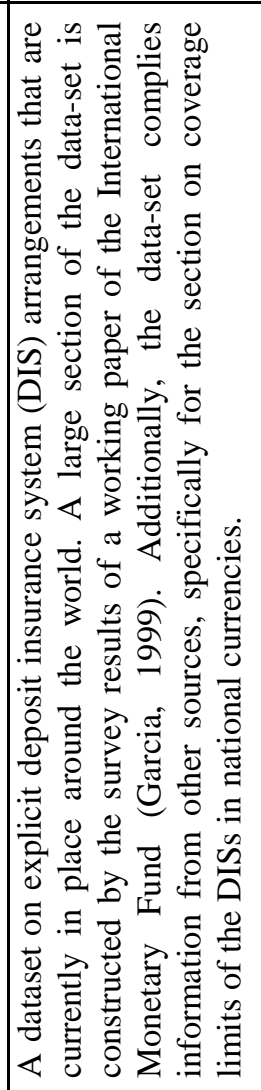 & 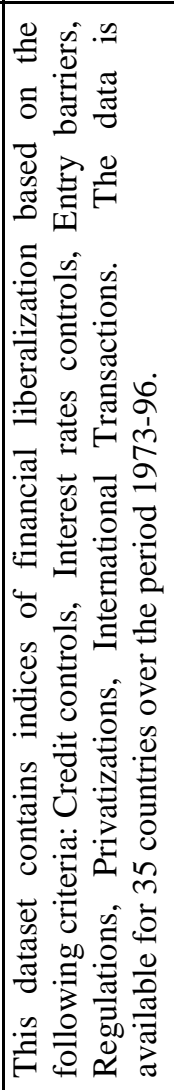 & 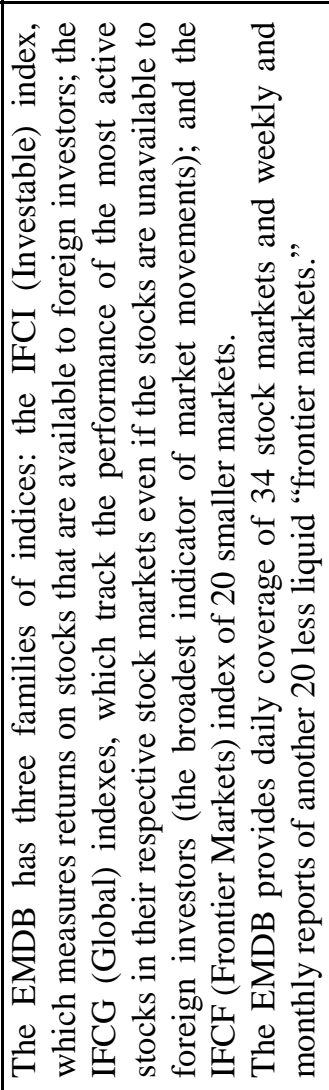 \\
\hline 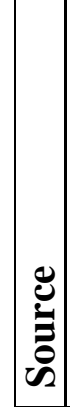 & 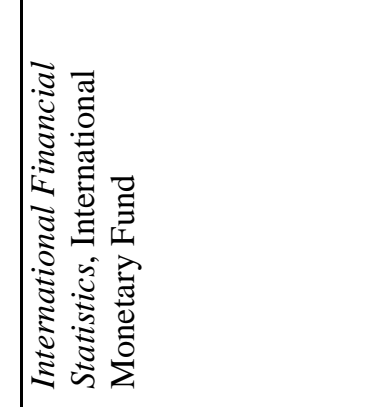 & 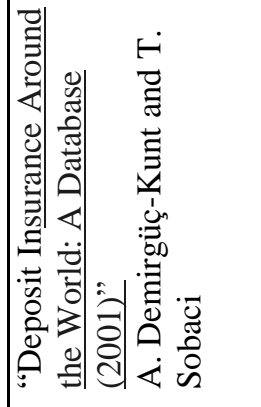 & 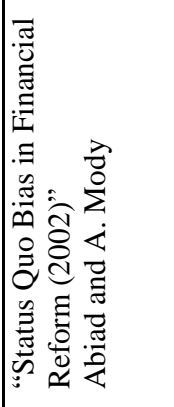 & 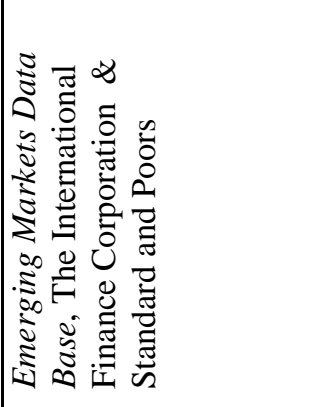 \\
\hline
\end{tabular}




\begin{tabular}{|c|c|c|c|c|}
\hline 告 & 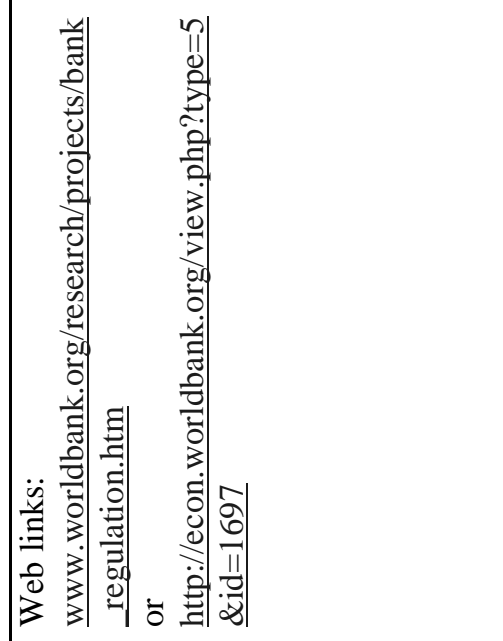 & |⿱一𫝀) & 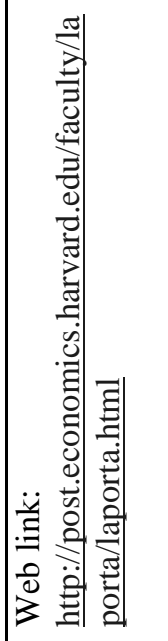 & 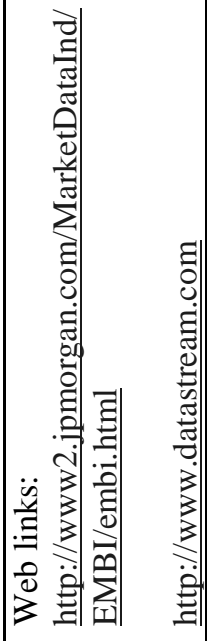 \\
\hline 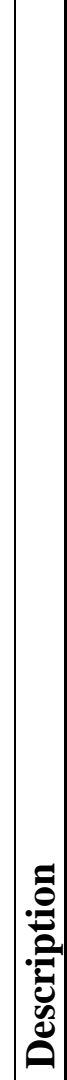 & 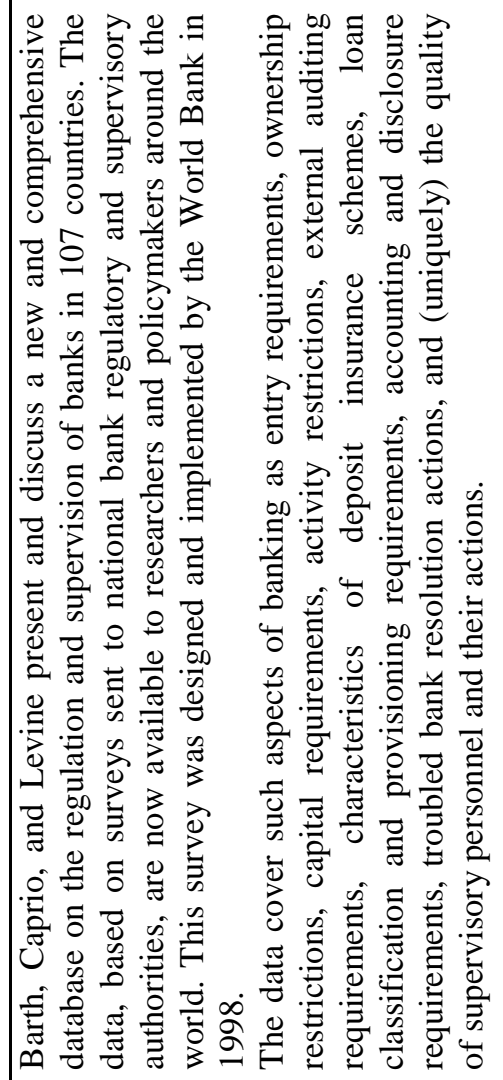 & 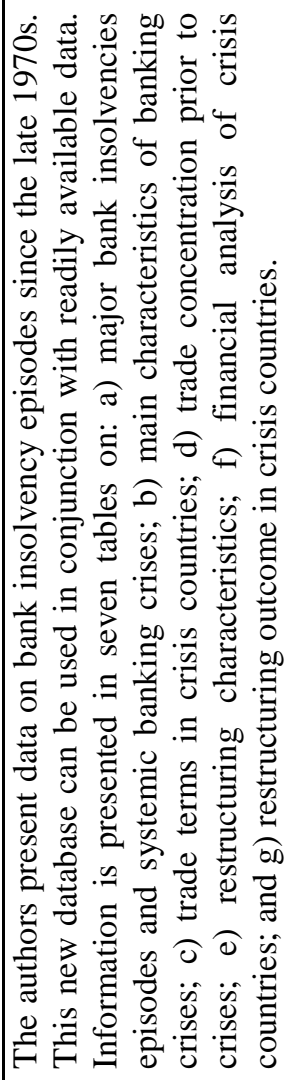 & 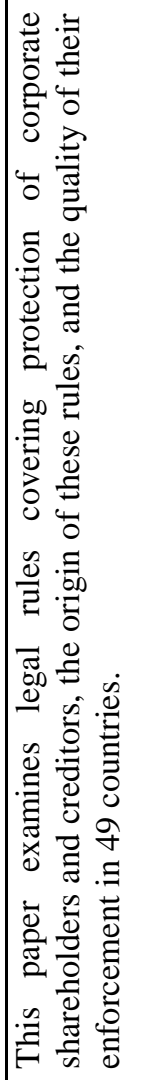 & 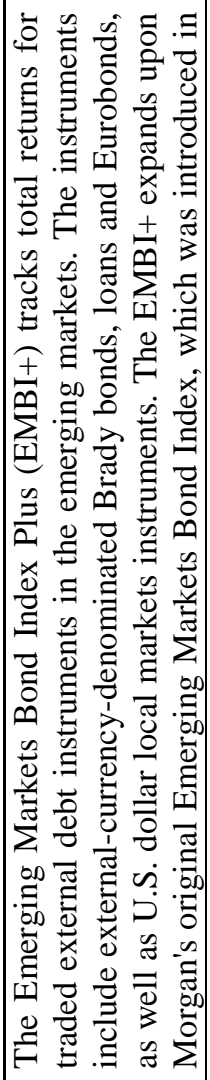 \\
\hline 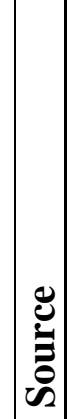 & 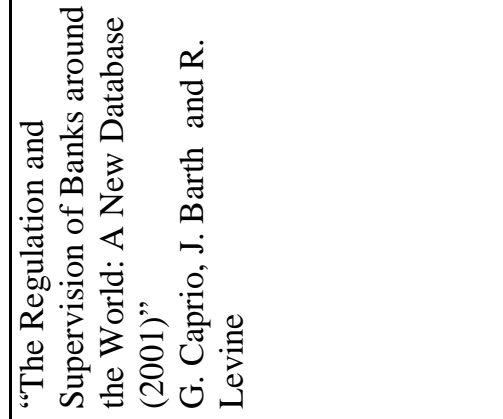 & 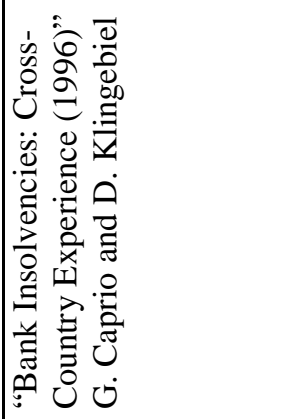 & 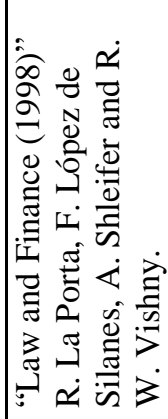 & 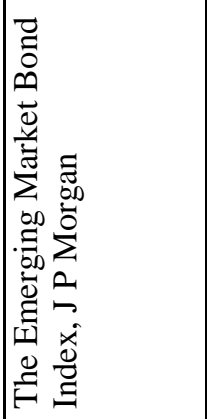 \\
\hline
\end{tabular}




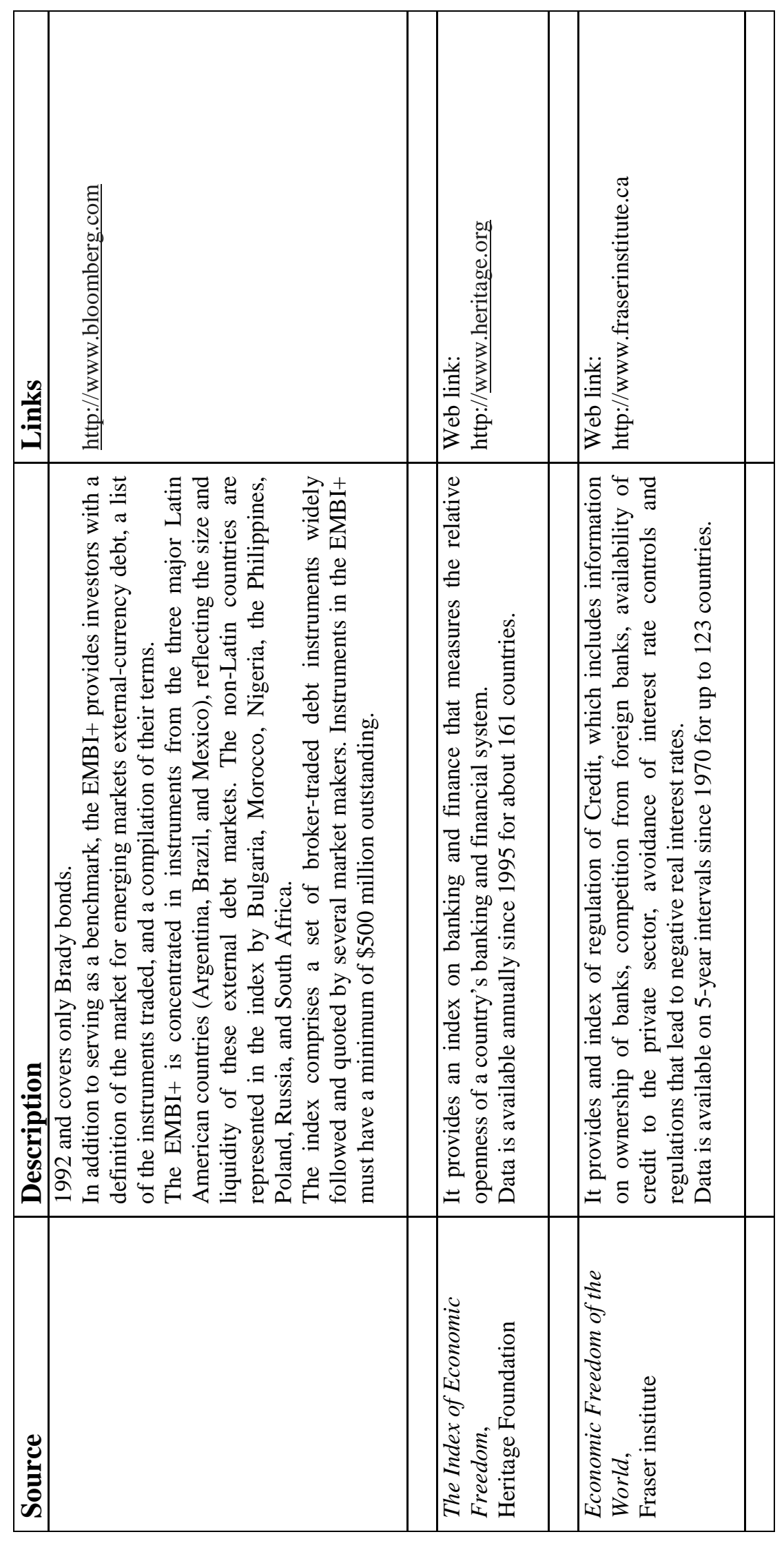


n

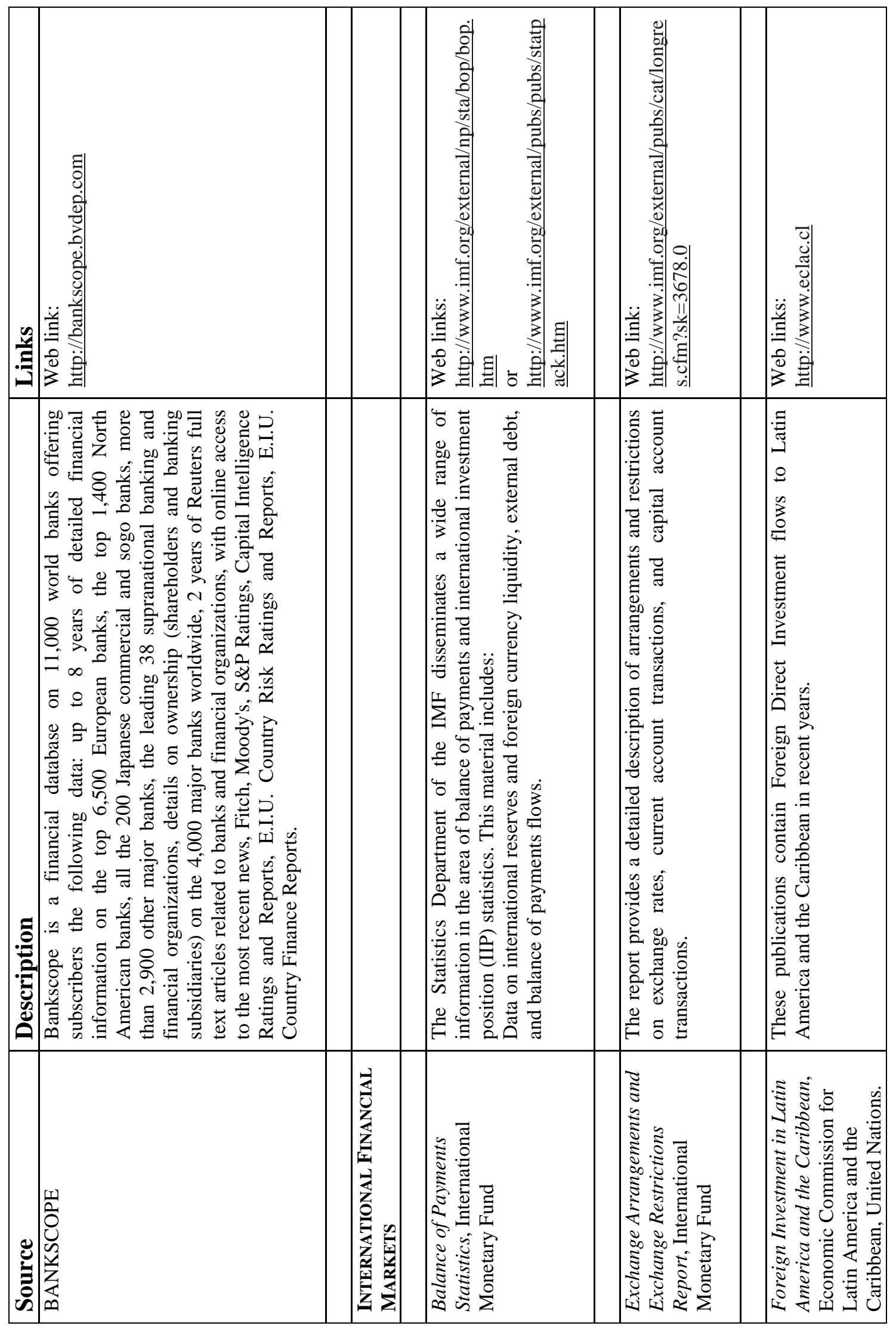




\begin{tabular}{|c|c|c|c|c|c|}
\hline 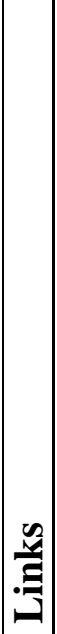 & 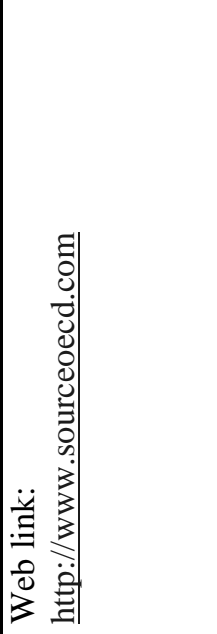 & 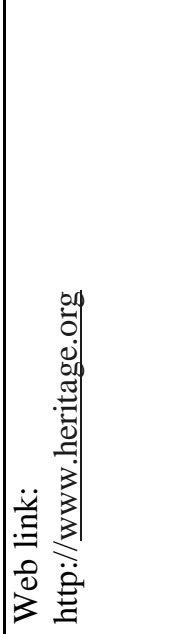 & 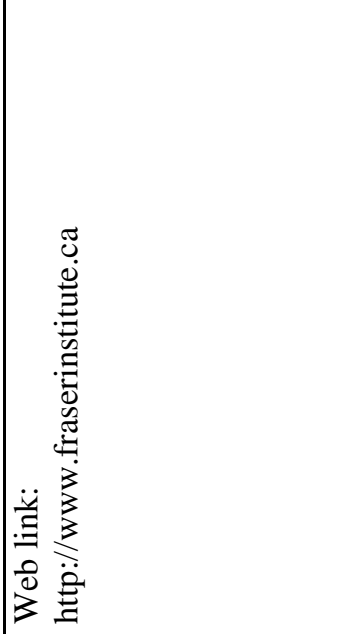 & & 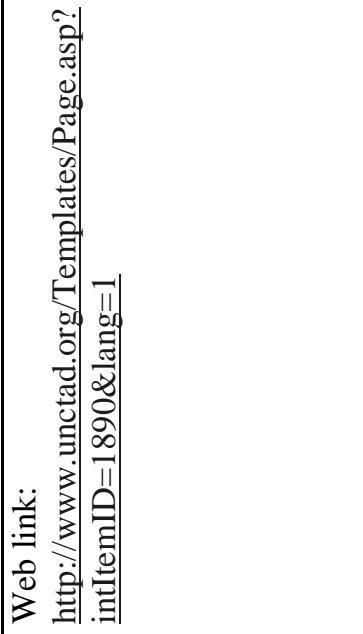 \\
\hline 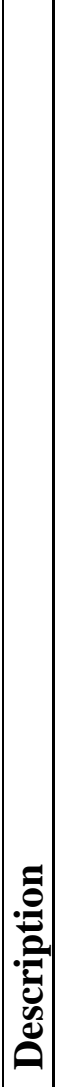 & 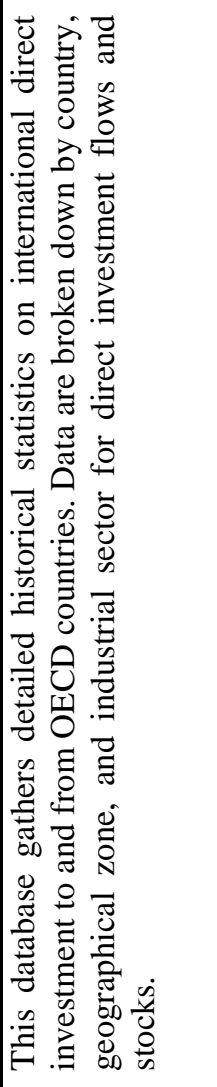 & 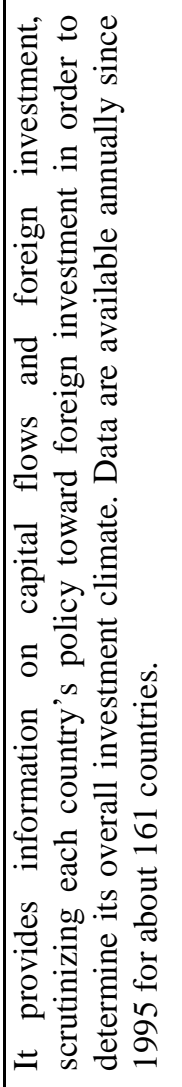 & 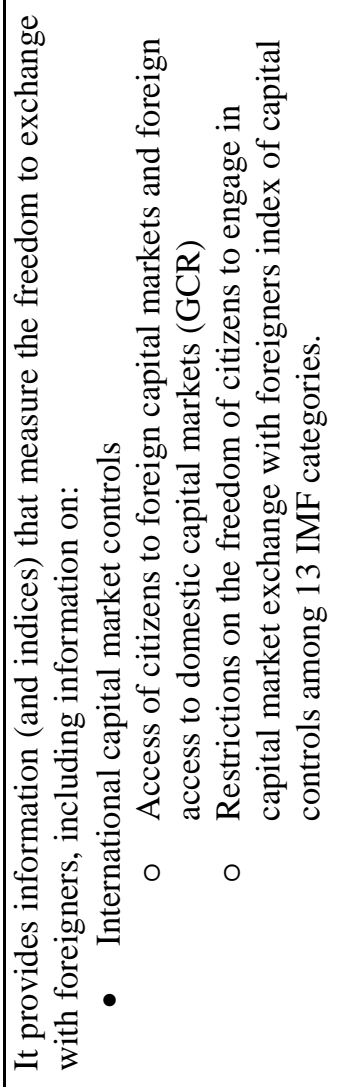 & & 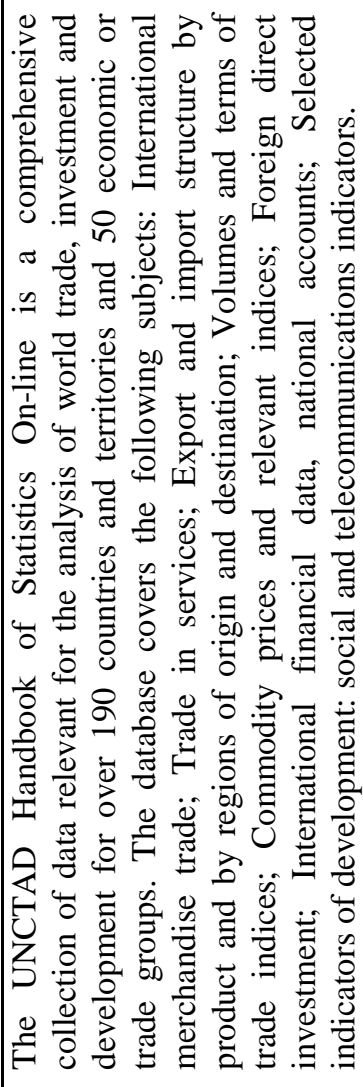 \\
\hline 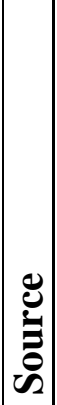 & 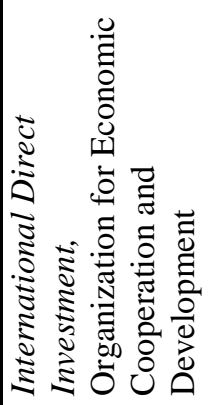 & 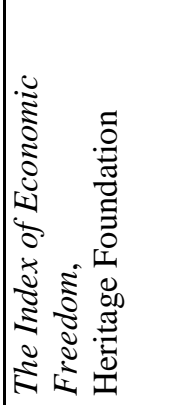 & 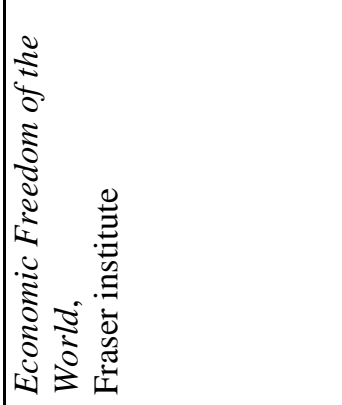 & 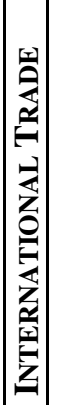 & 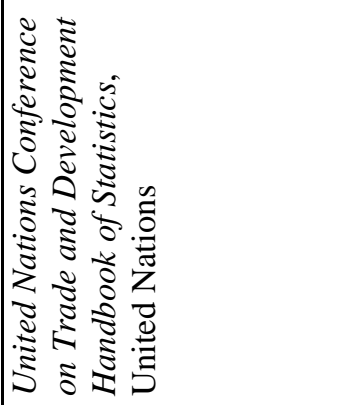 \\
\hline
\end{tabular}


in

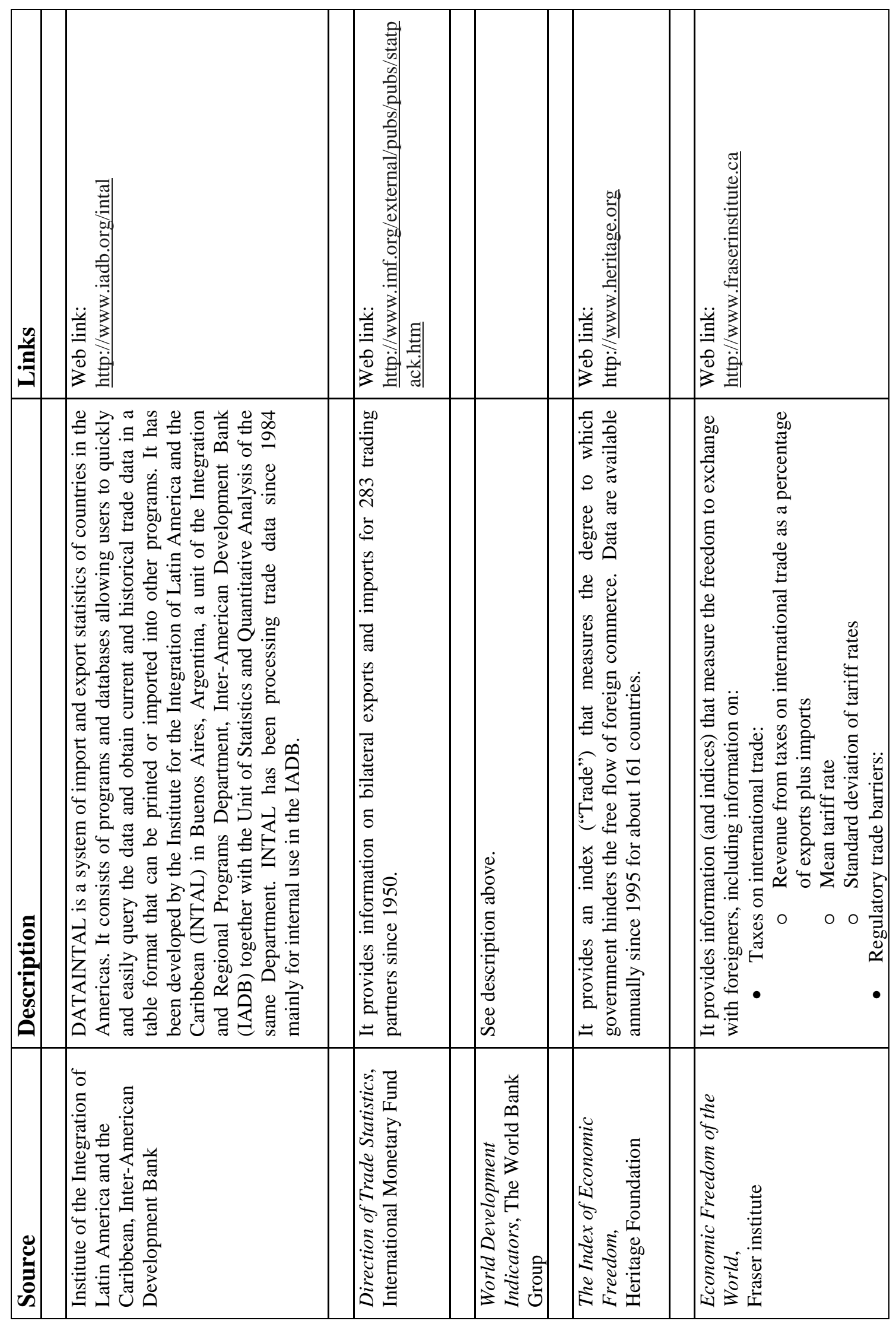




\begin{tabular}{|c|c|c|c|c|}
\hline 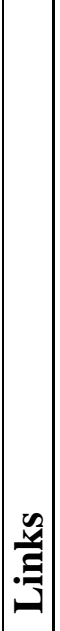 & & & 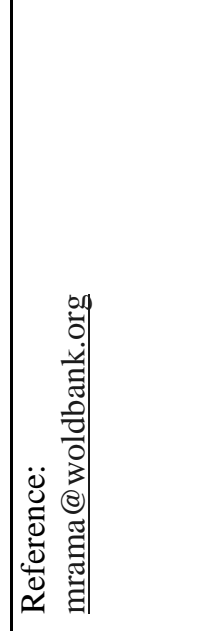 & 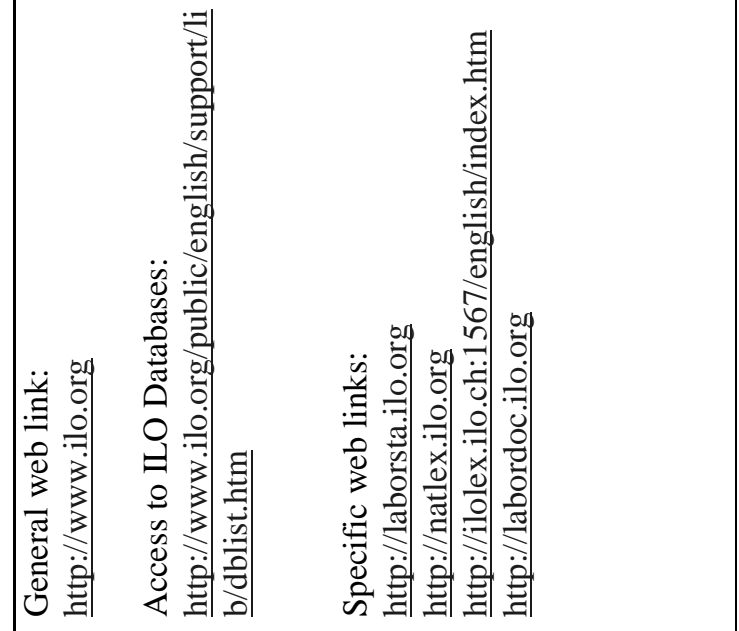 \\
\hline 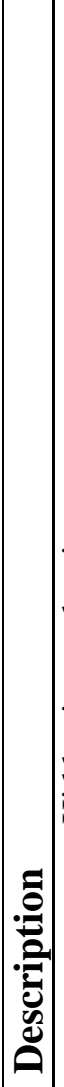 & 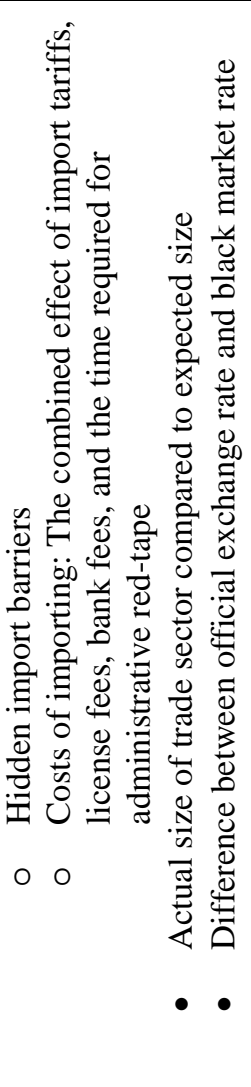 & & 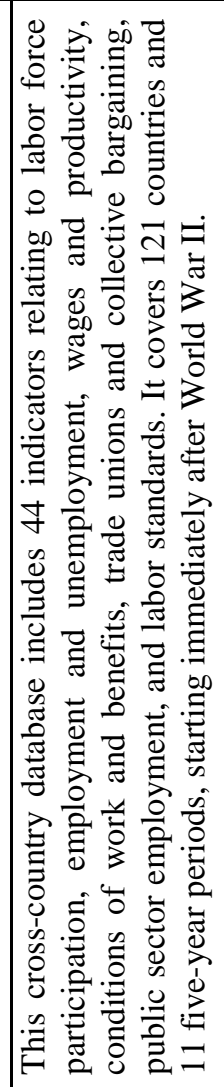 & 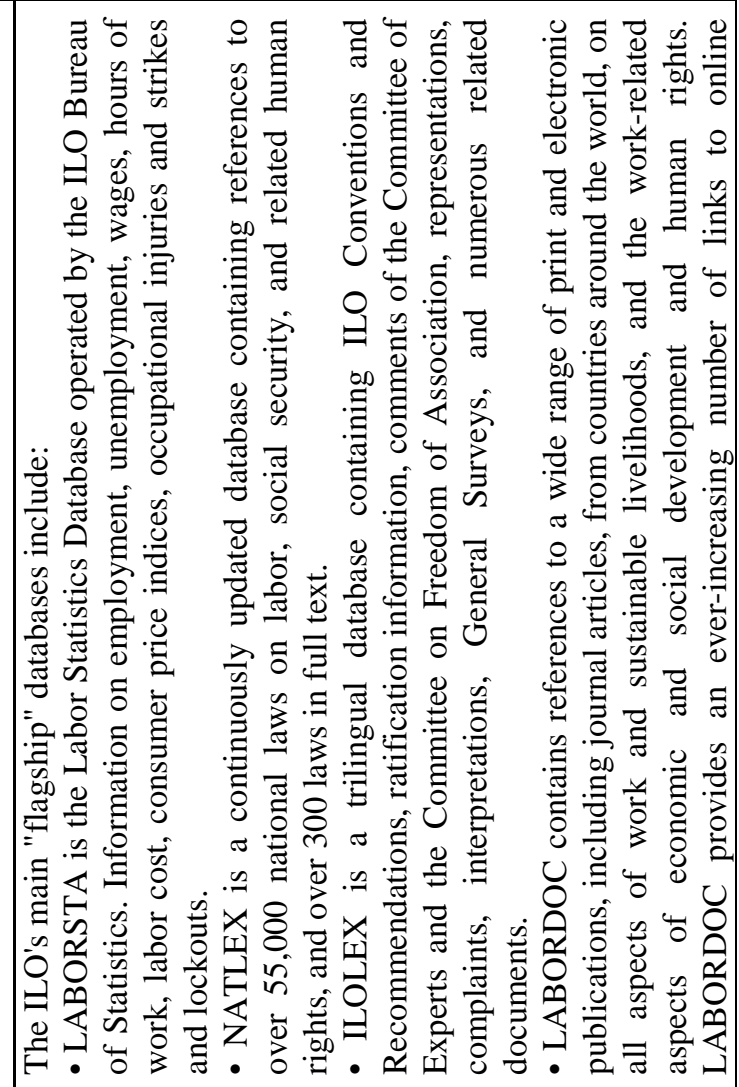 \\
\hline $\mathscr{n}$ & & 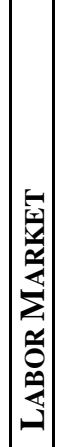 & 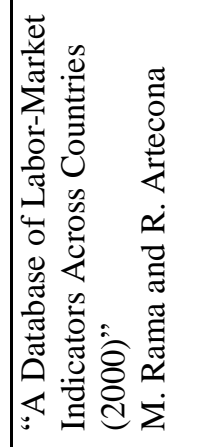 & 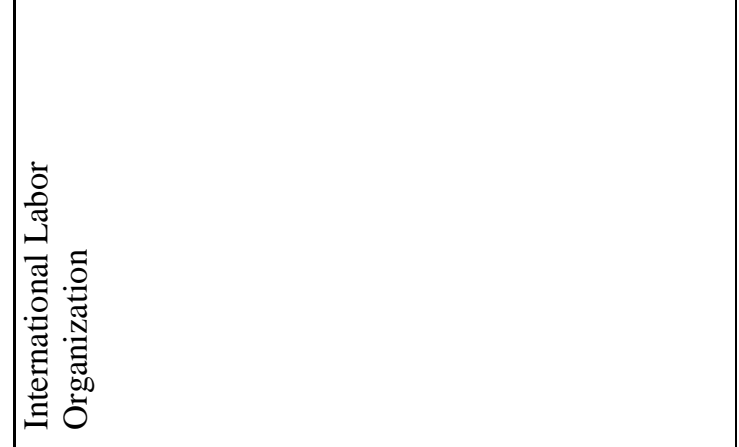 \\
\hline
\end{tabular}


in

\begin{tabular}{|c|c|c|c|c|c|c|c|}
\hline 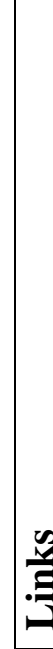 & & & 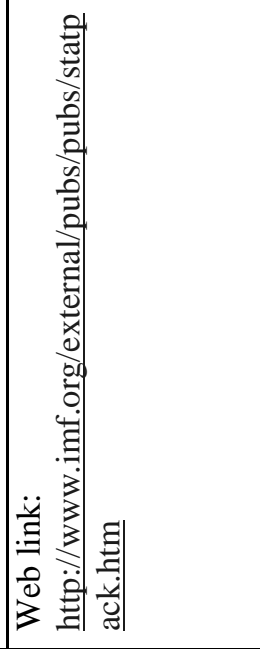 & \multicolumn{2}{|c|}{ 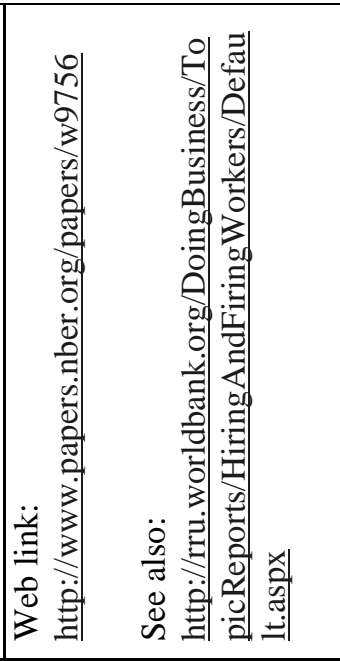 } & 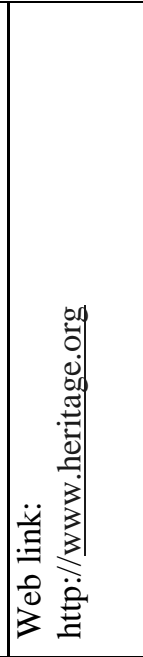 & 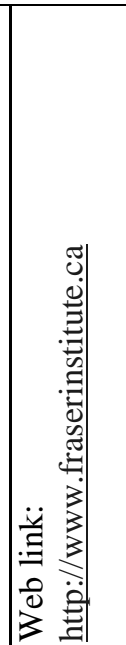 \\
\hline & 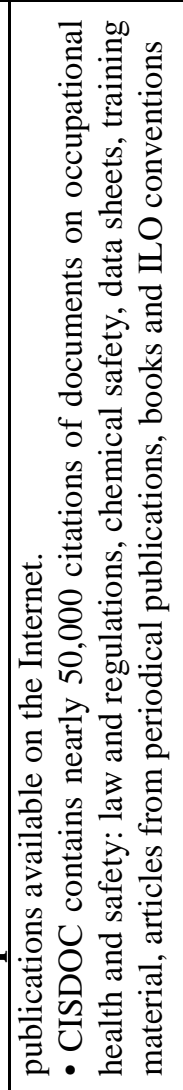 & 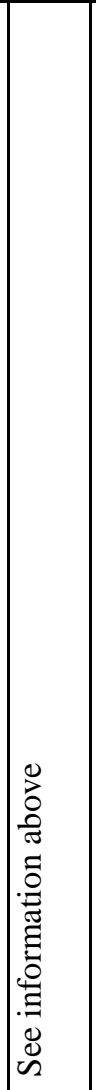 & 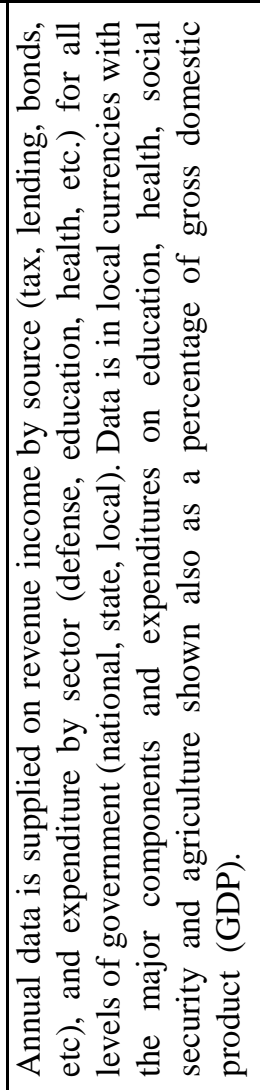 & 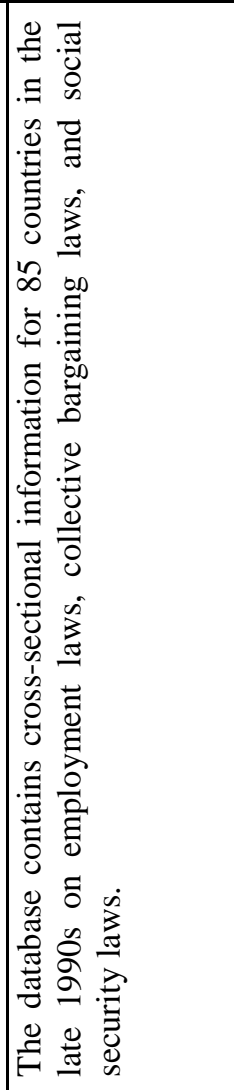 & & 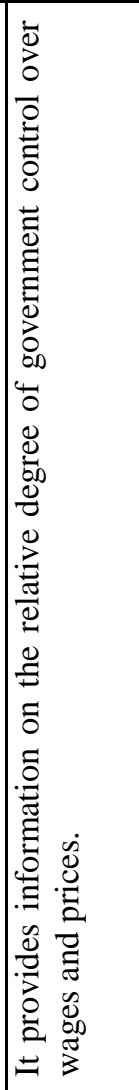 & 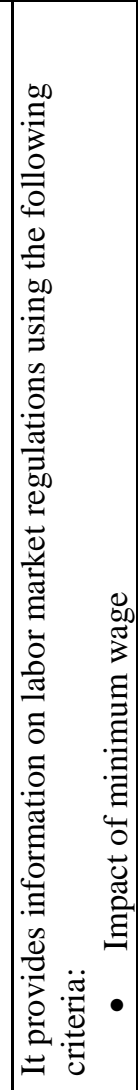 \\
\hline & & 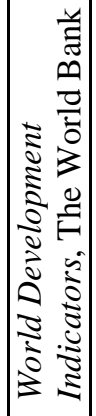 & 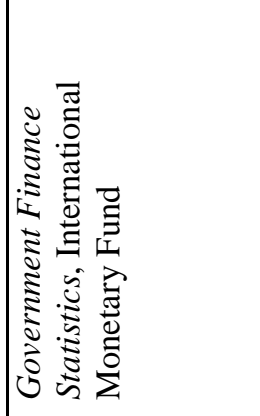 & 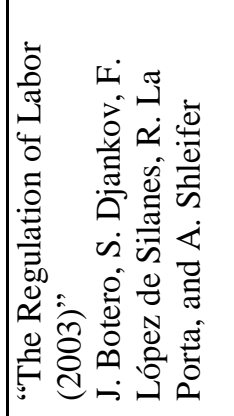 & 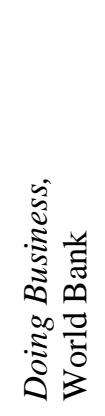 & 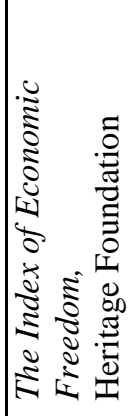 & 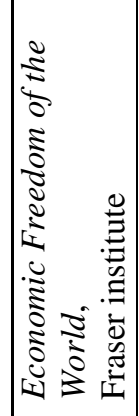 \\
\hline
\end{tabular}




\begin{tabular}{|c|c|c|c|c|c|c|}
\hline $\mid$ & & & & 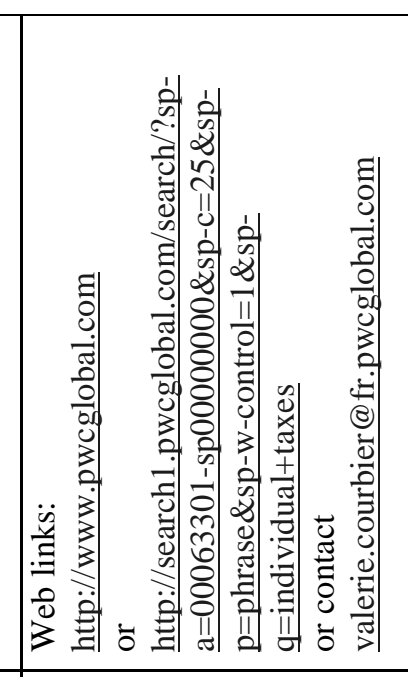 & 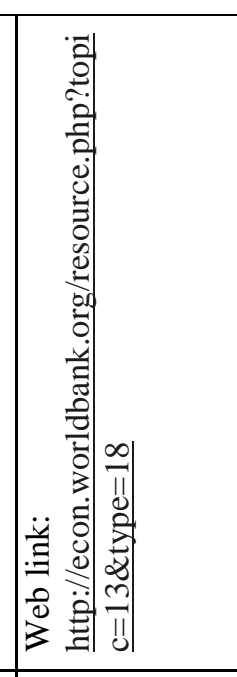 & \\
\hline 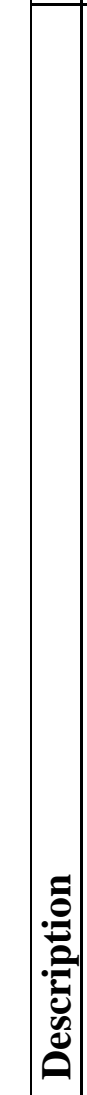 & 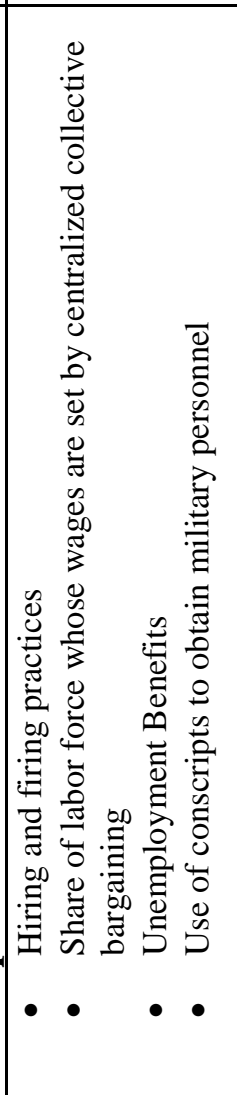 & & 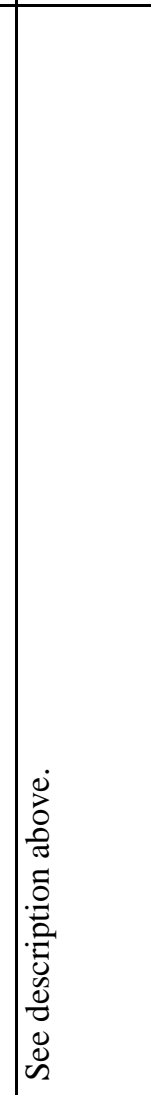 & 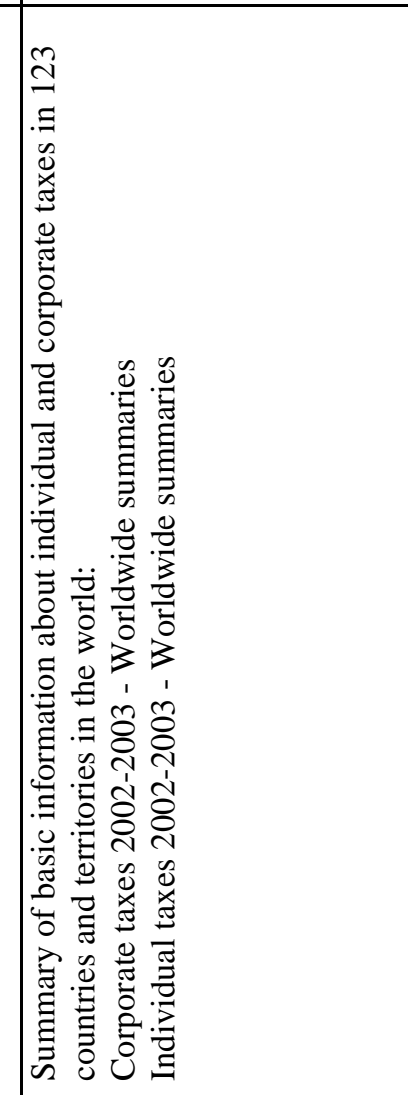 & 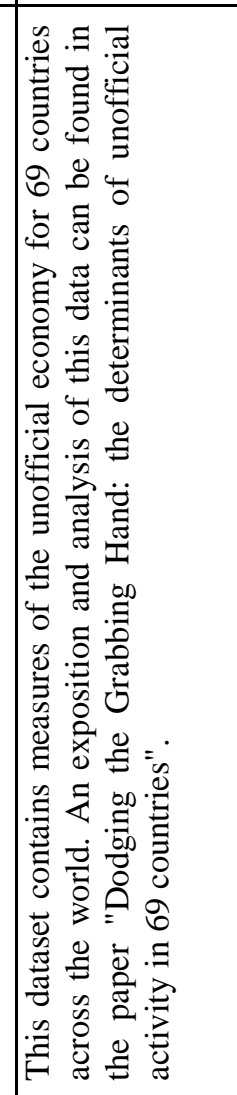 & 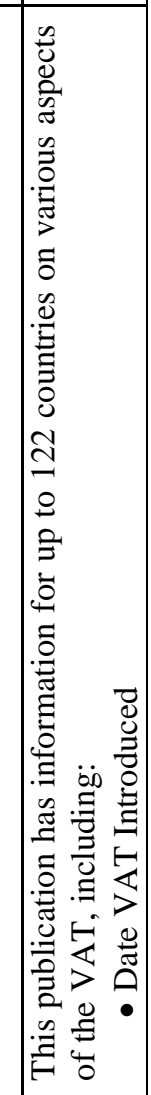 \\
\hline 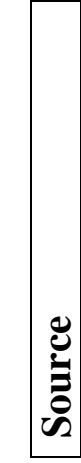 & & 17 & 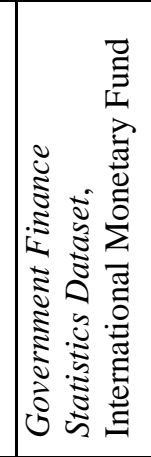 & 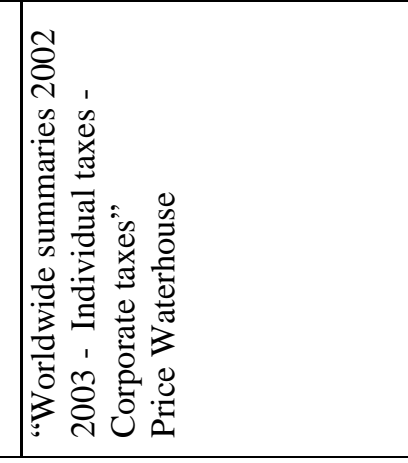 & 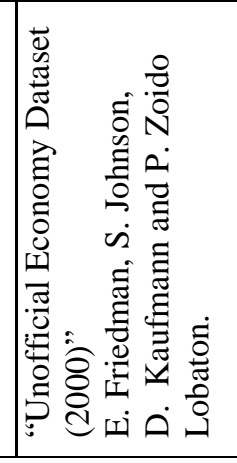 & 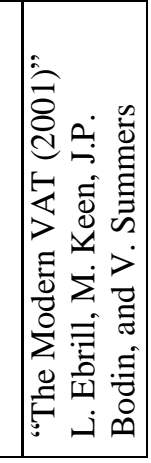 \\
\hline
\end{tabular}


in

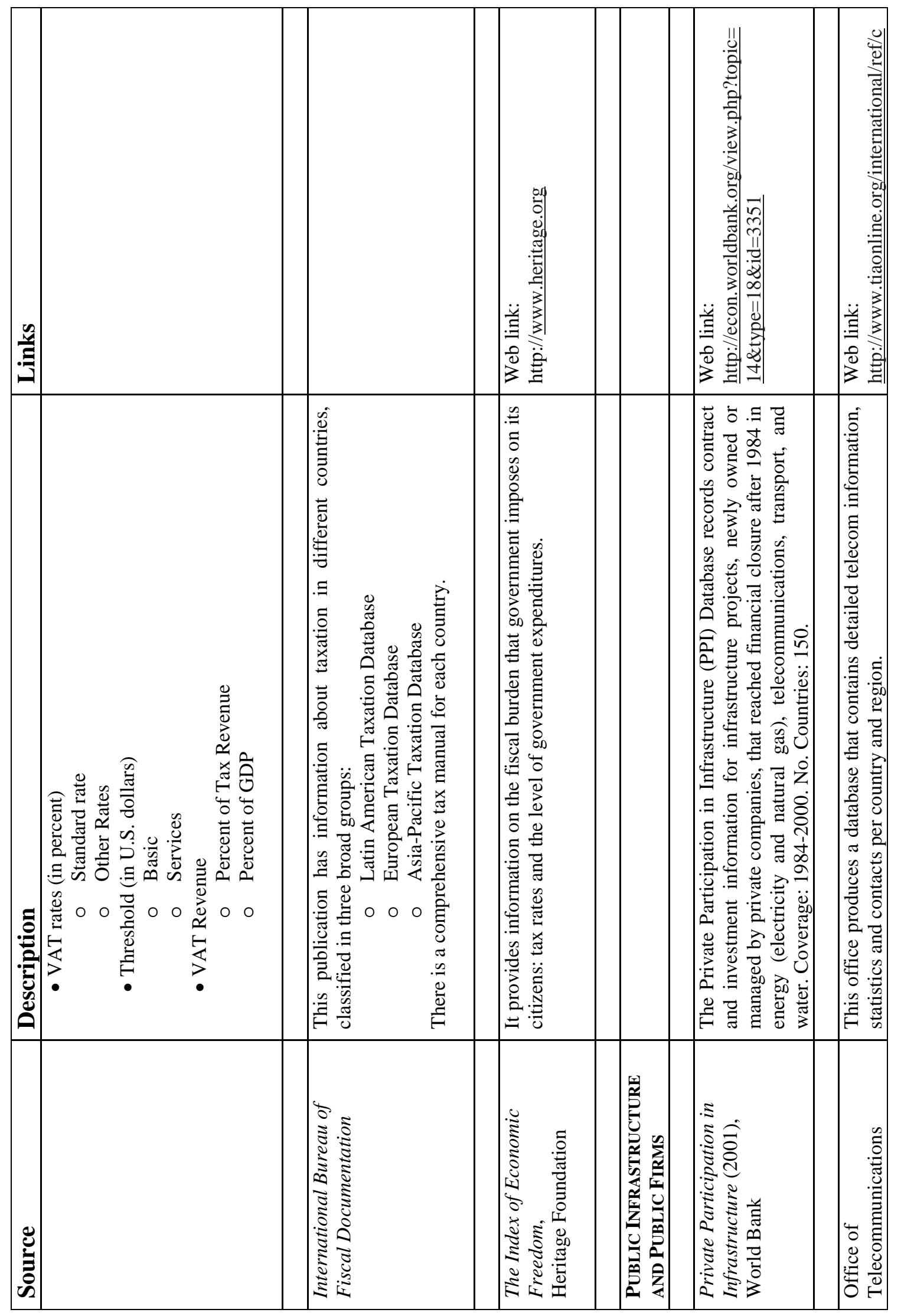




\begin{tabular}{|c|c|c|c|c|}
\hline$\frac{\mathscr{n}}{3}$ & 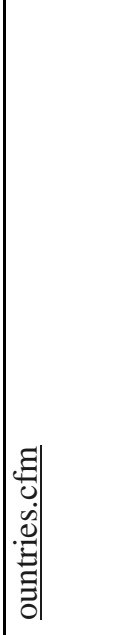 & 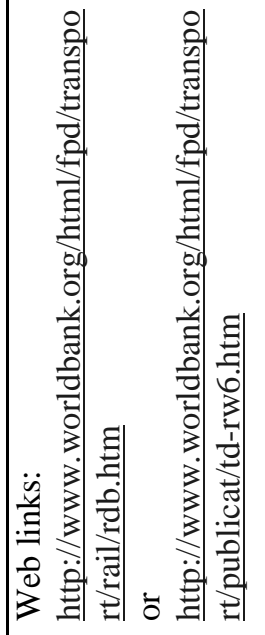 & 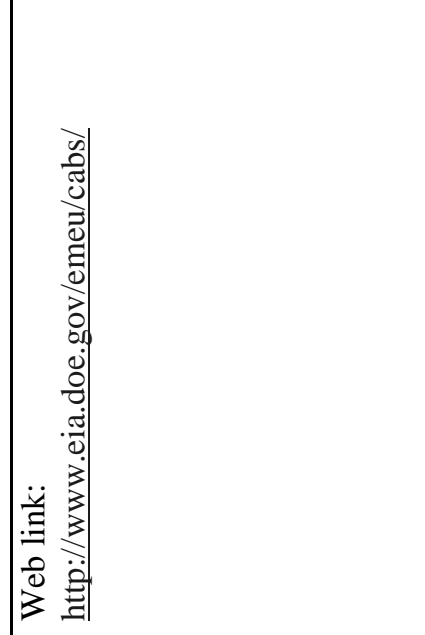 & 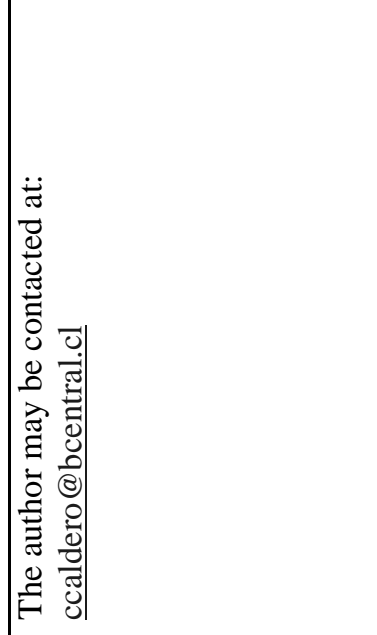 \\
\hline | & & 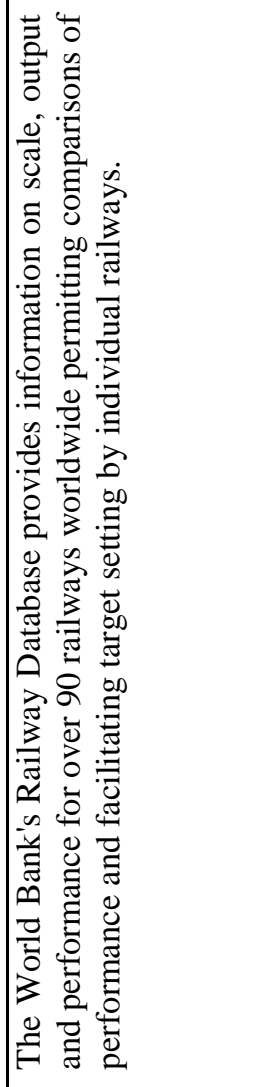 & 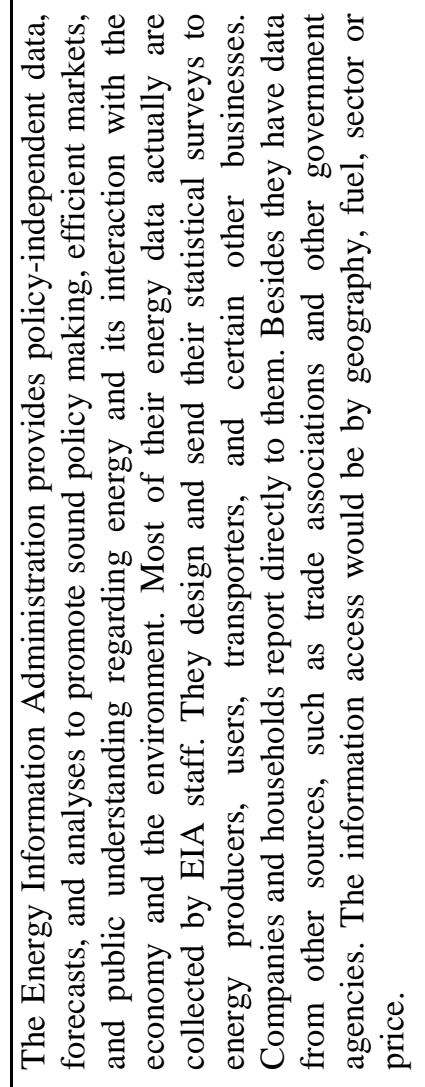 & 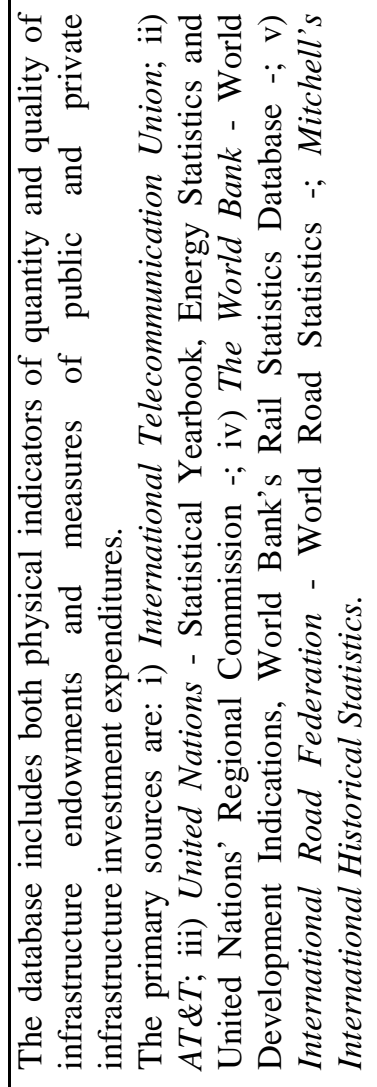 \\
\hline & 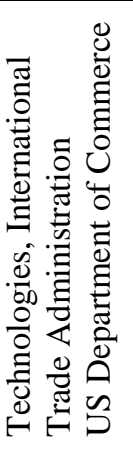 & 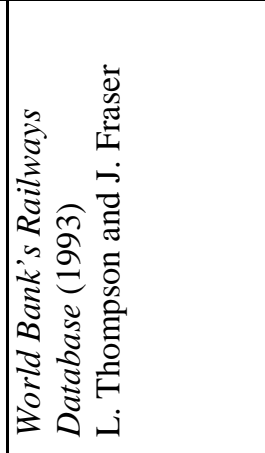 & 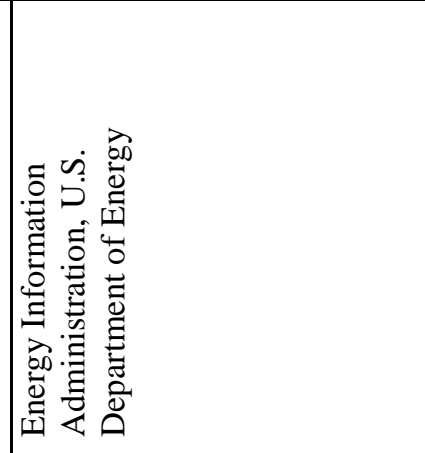 & 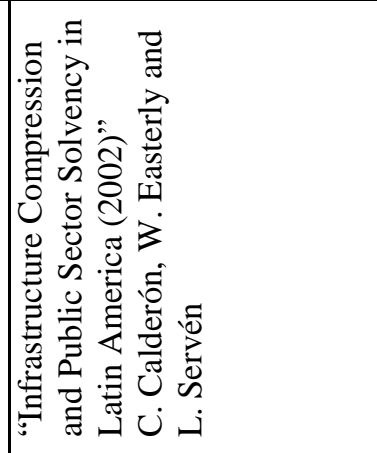 \\
\hline
\end{tabular}




\begin{tabular}{|c|c|c|c|c|c|c|}
\hline & 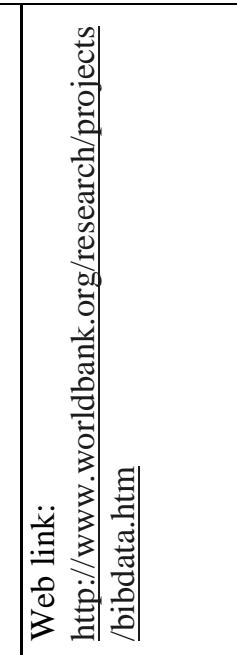 & 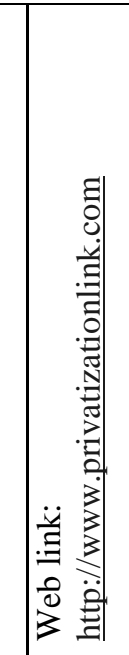 & 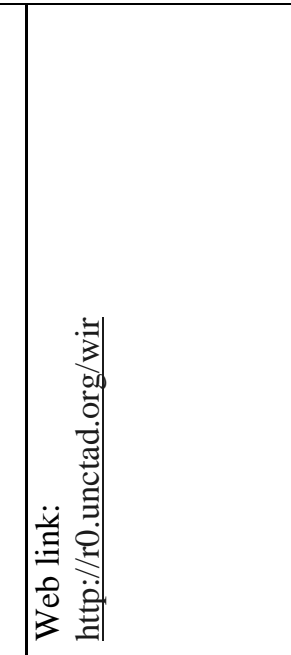 & & 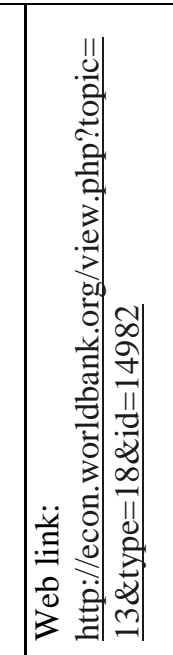 & 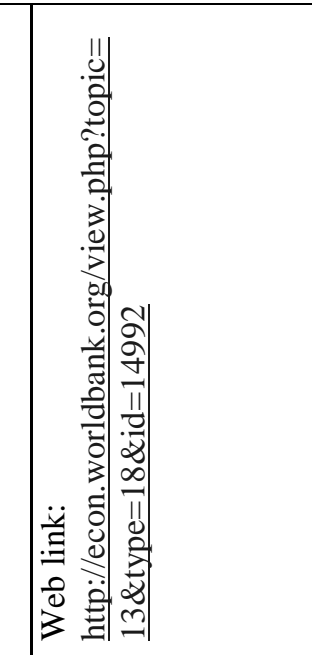 \\
\hline & 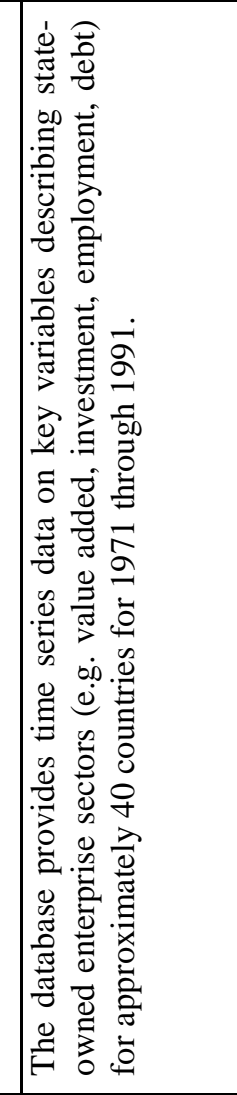 & 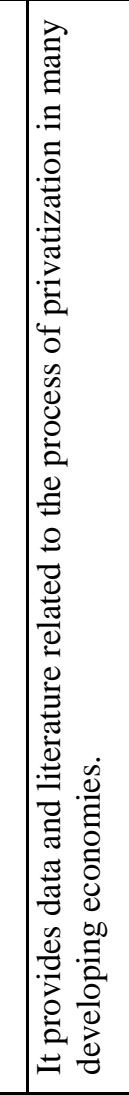 & 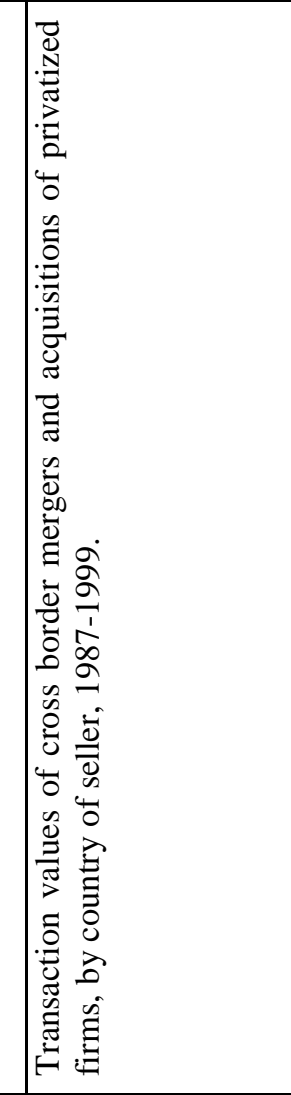 & & 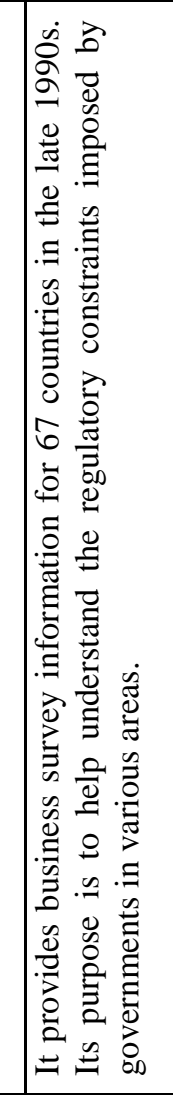 & 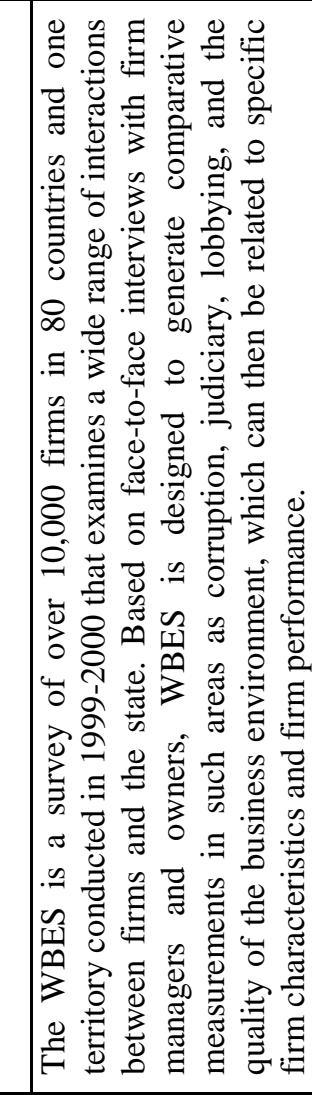 \\
\hline & 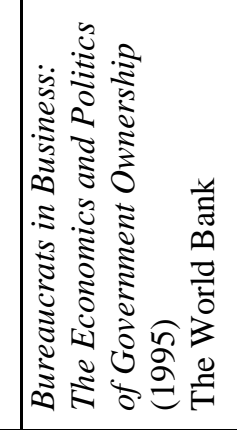 & 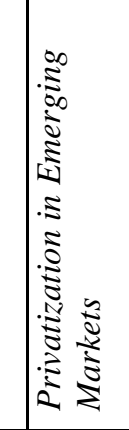 & 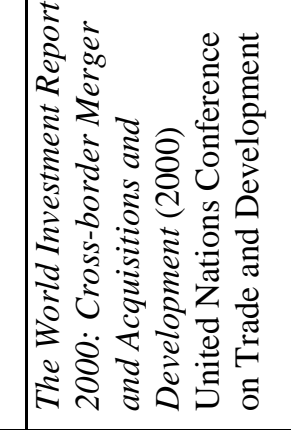 & 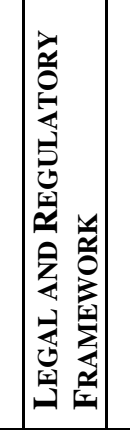 & 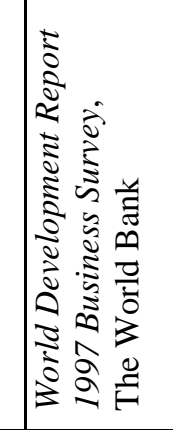 & 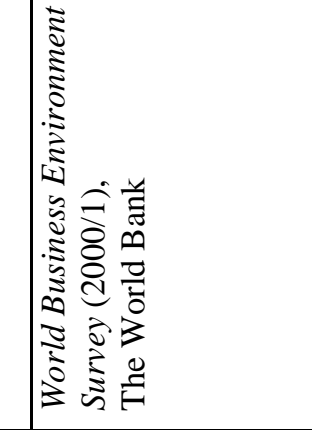 \\
\hline
\end{tabular}




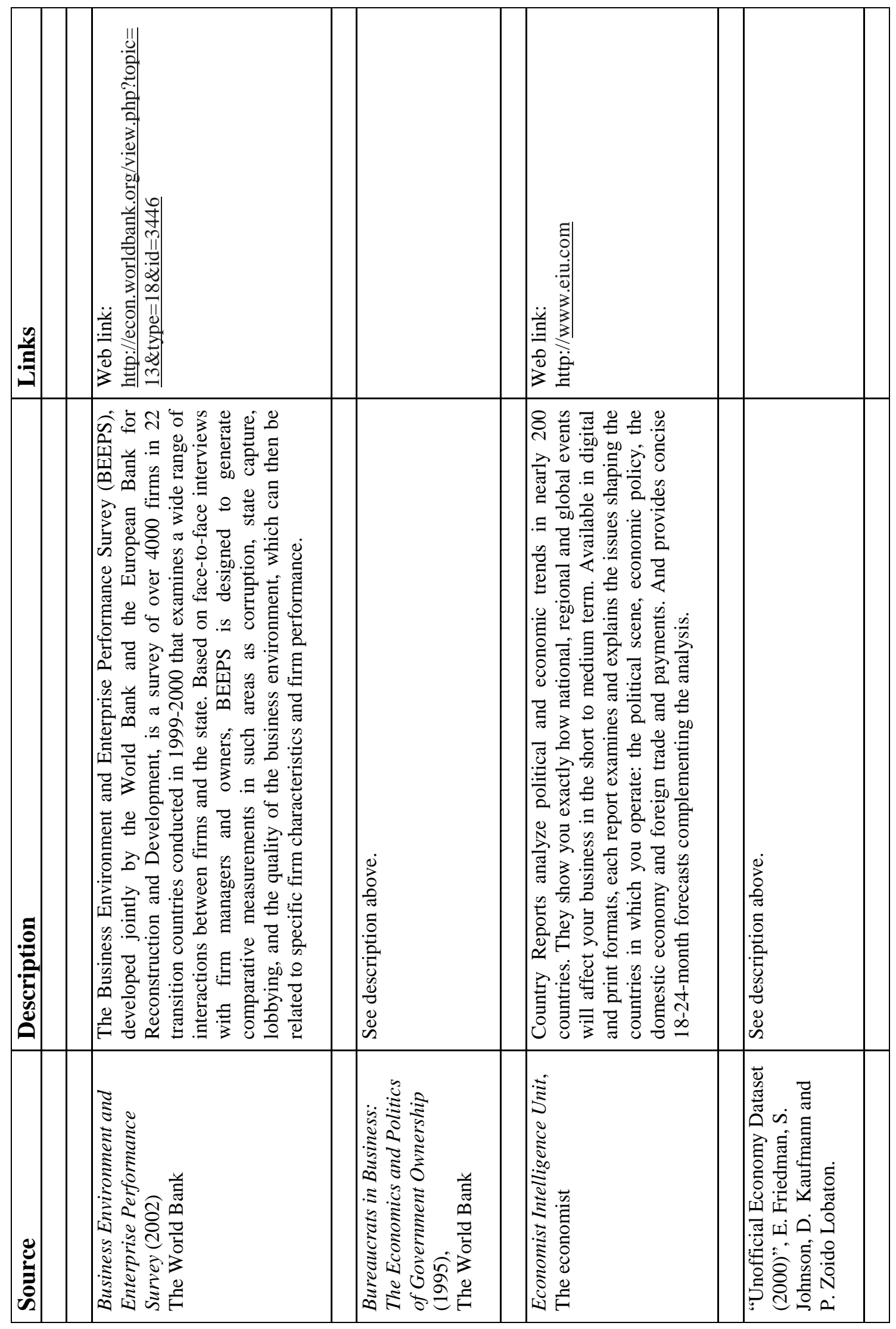




\begin{tabular}{|c|c|c|c|c|c|c|c|}
\hline & 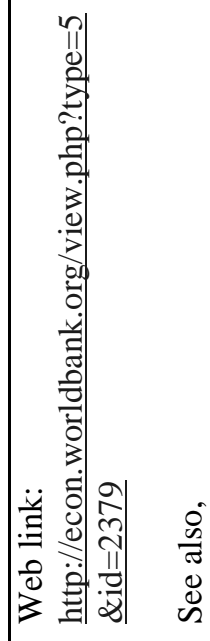 & 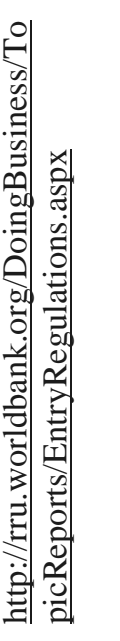 & 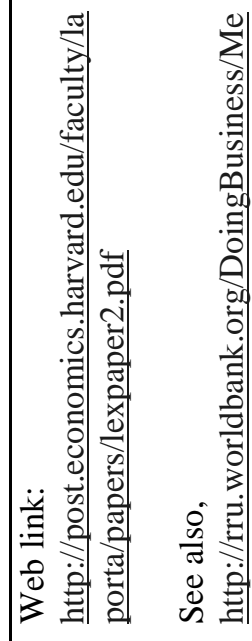 & & 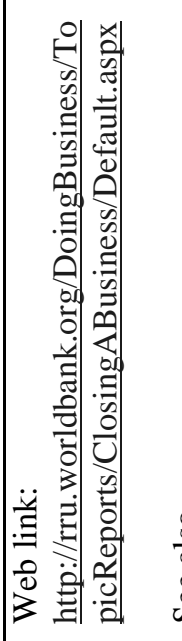 & 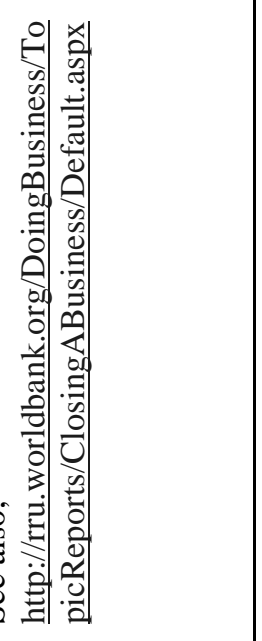 & 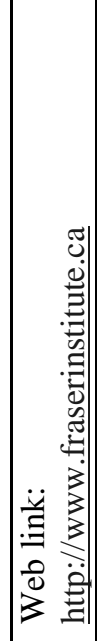 \\
\hline & 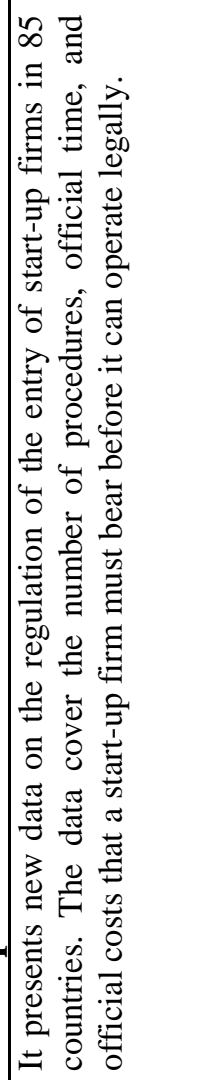 & & 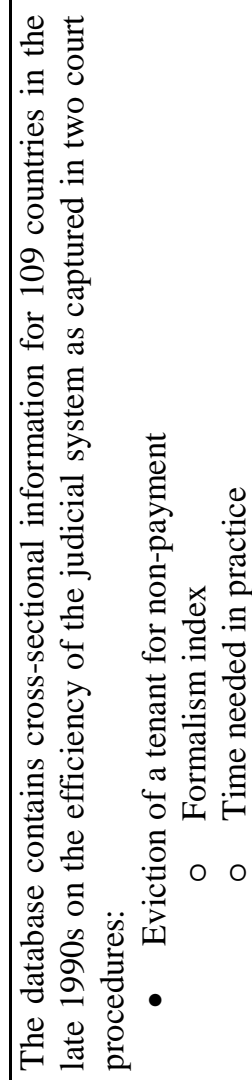 & 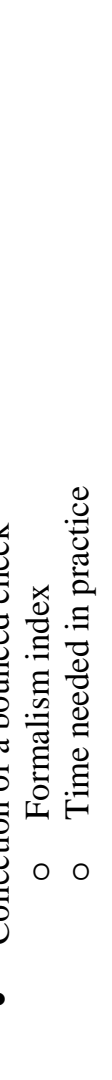 & 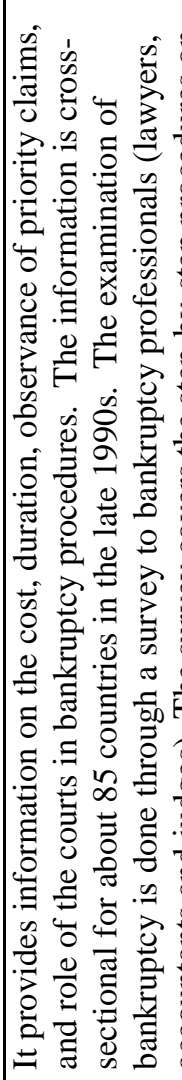 & 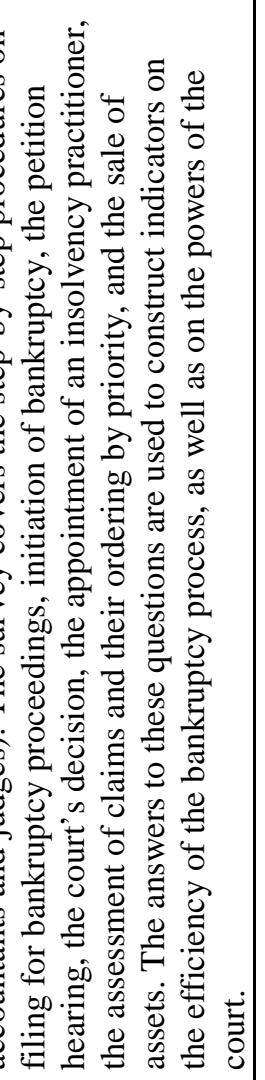 & 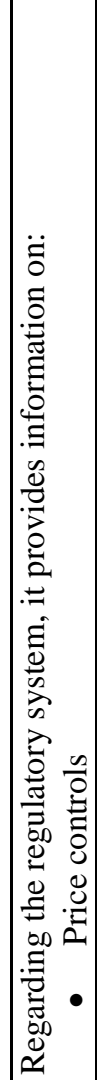 \\
\hline 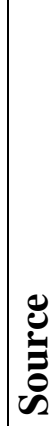 & 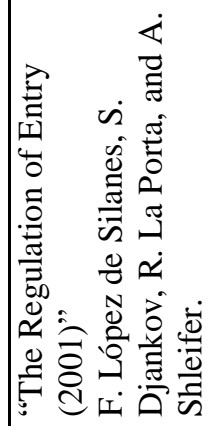 & 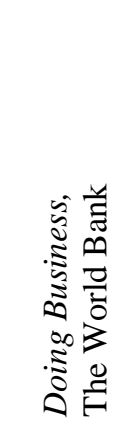 & 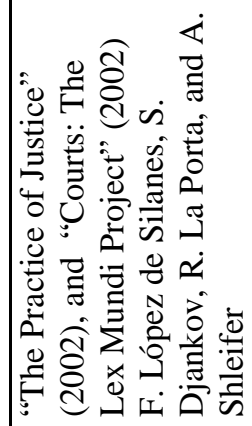 & 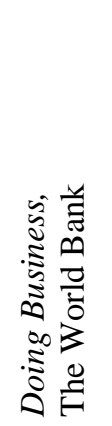 & 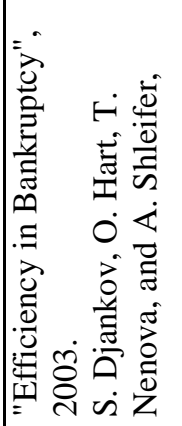 & 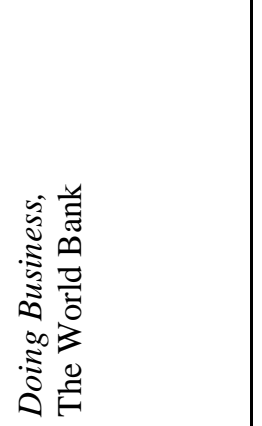 & 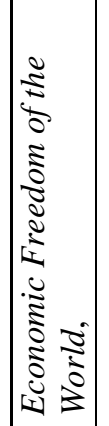 \\
\hline
\end{tabular}




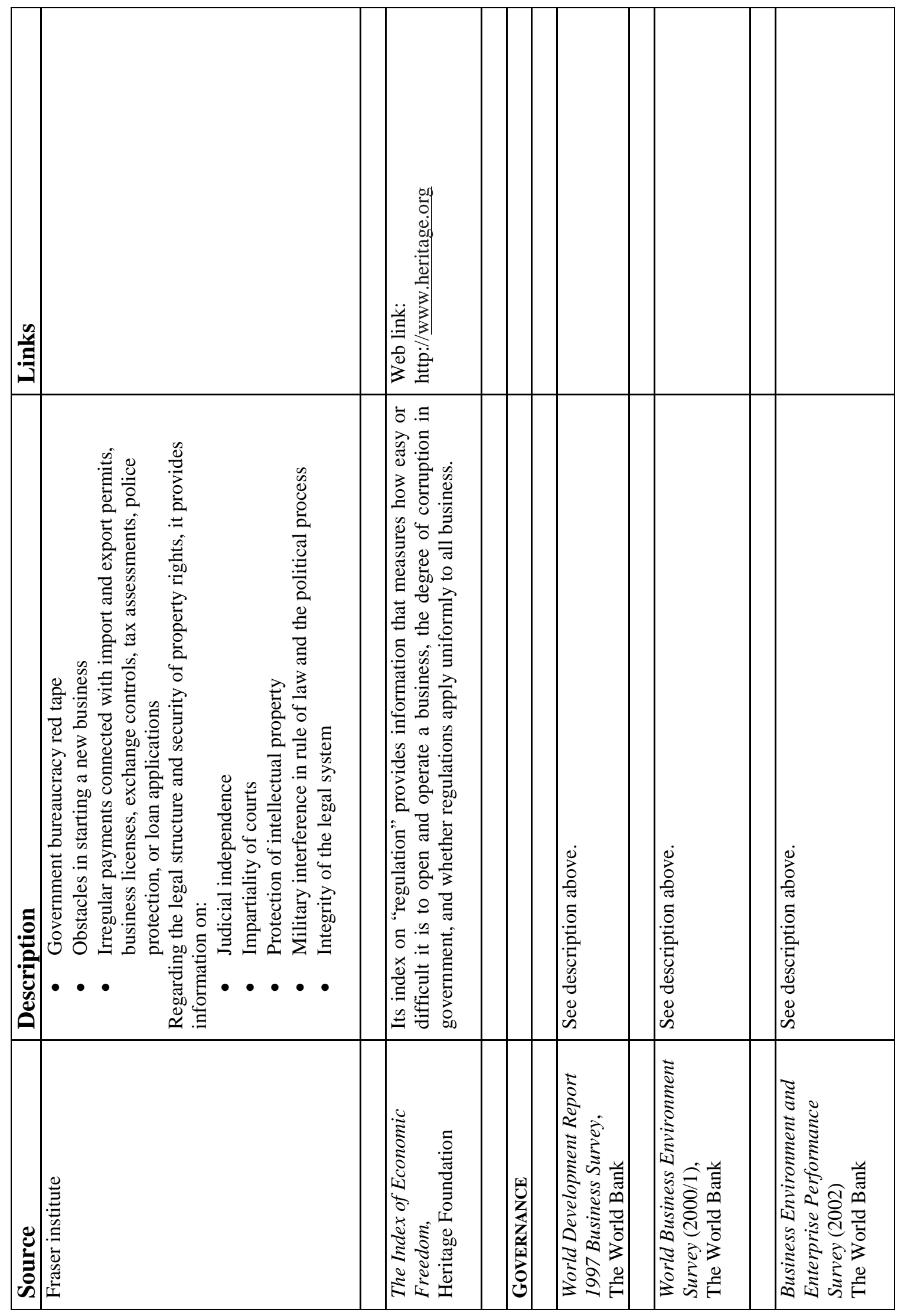




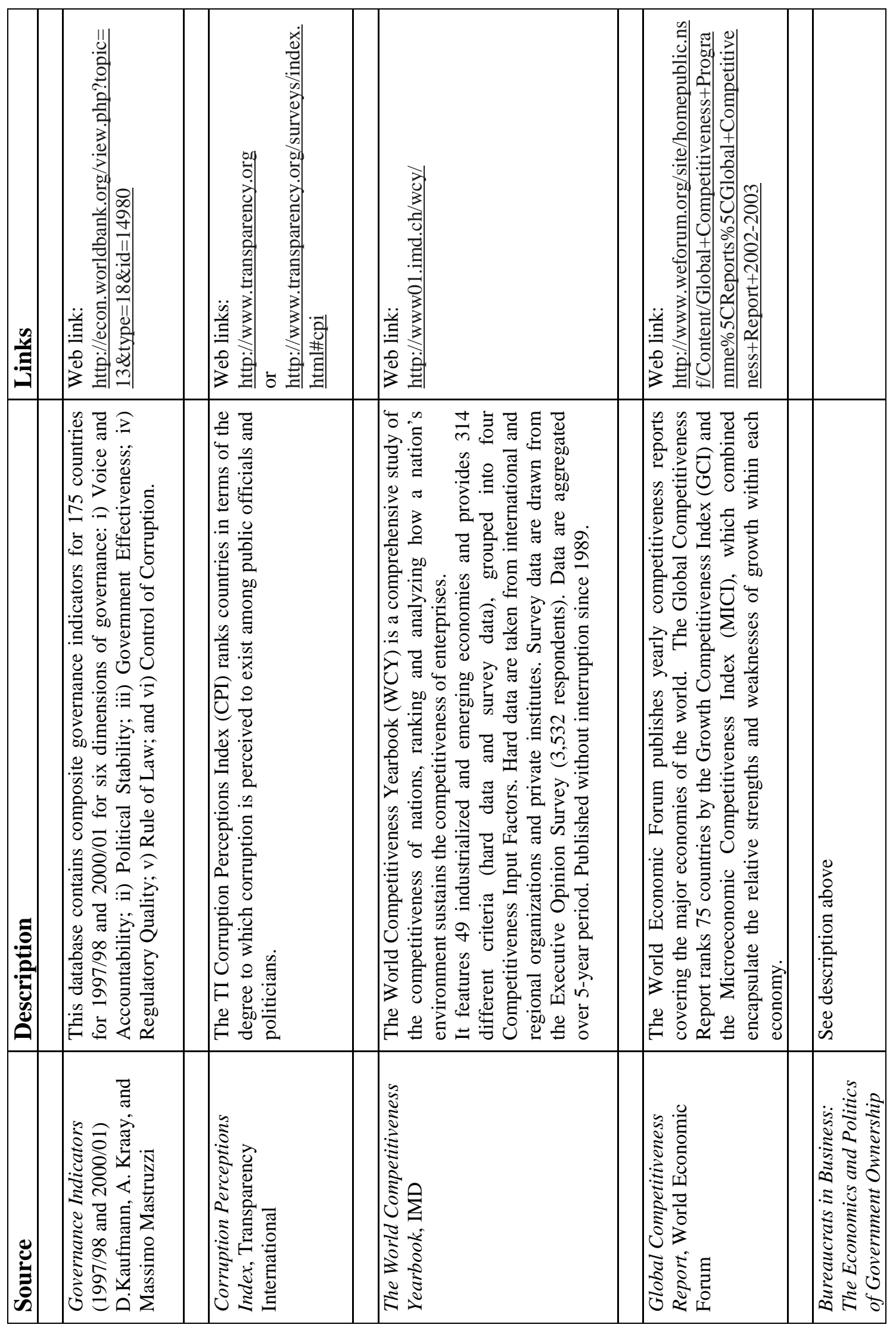




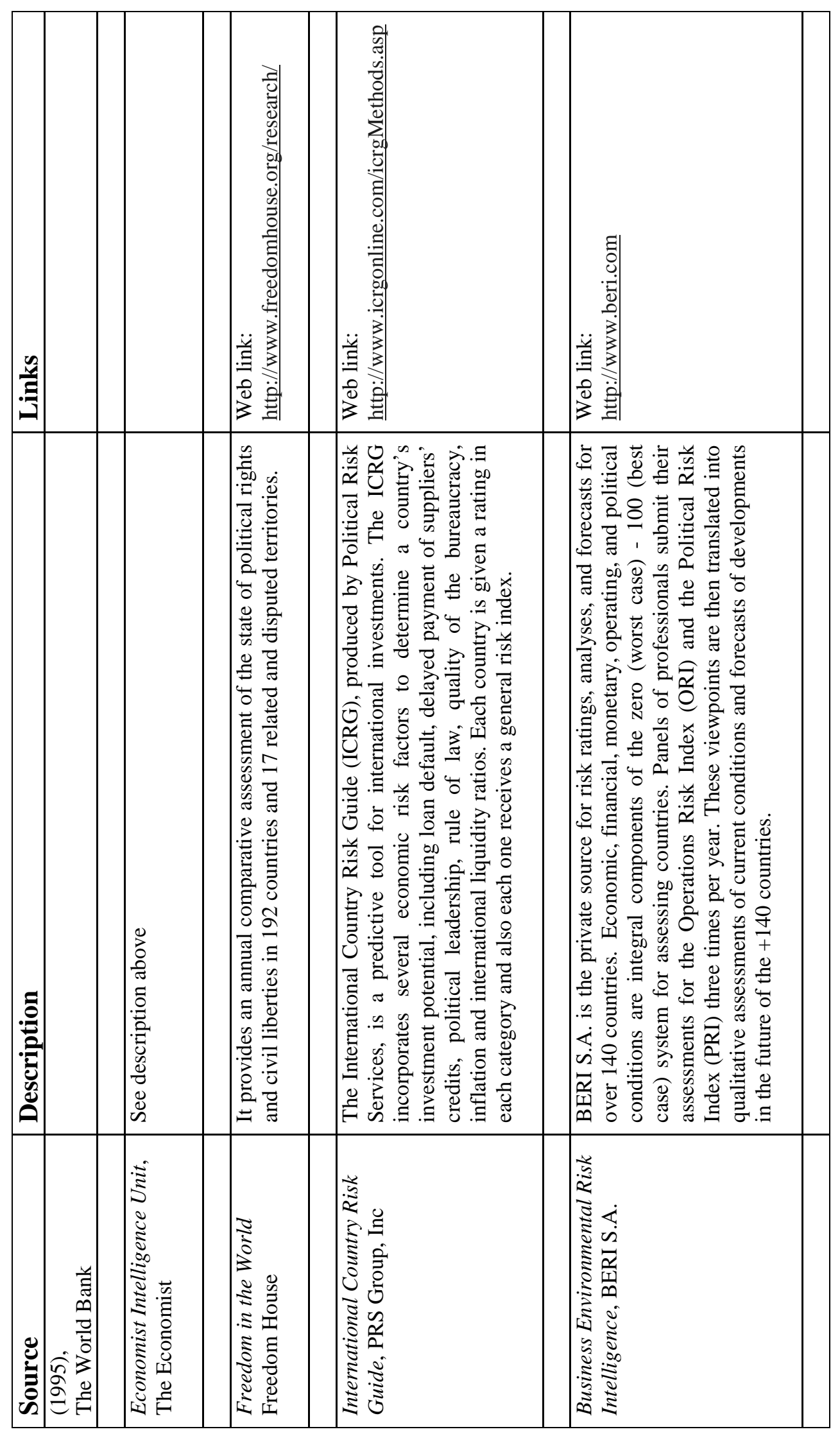

